\title{
Minireview
}

\section{Nitric Oxide Production and Nitric Oxide Synthase Type 2 Expression by Human Mononuclear Phagocytes: A Review}

\section{J. Brice Weinberg}

VA and Duke University Medical Centers, Durham, North Carolina, U.S.A.

\section{Introduction}

Nitric oxide (NO) plays important roles in physiology and pathology. This small molecule regulates smooth muscle tone, functions as a neurotransmitter, regulates cellular proliferation, and protects the host against neoplasia and infection (1). NO may also mediate deleterious effects. For example, it appears to be important in inflammation, carcinogenesis, aging, and neurotoxicity ( $1-$ 3). NO is produced from L-arginine by the actions of NO synthases (NOS), a family of enzymes encoded by separate genes $(4,5)$. Neuronal NOS (NOS1, found mainly in neuronal cells and skeletal muscle cells) and endothelial NOS (NOS3, found mainly in endothelial cells) are produced constitutively. Their actions are controlled in large part by changes in intracellular calcium concentrations, and NOS1 and NOS3 generate low-level NO production. Inducible NOS (iNOS or NOS2) is expressed by numerous cell types, but mainly by mononuclear phagocytes, hepatocytes, chondrocytes, and smooth muscle cells $(5,6)$. Activity of NOS2 is controlled primarily by regulation of mRNA transcription and translation. Under proper conditions, NOS2 produces very high levels of NO.

The overall production of NOS2 and NO is influenced by many factors (Fig. 1). Regulation of NOS2 mRNA can occur at multiple steps (see ref. 5 for review), including mRNA transcription, mRNA stability, mRNA translation, and mRNA level (precise mechanisms not known). At the protein level, NOS may be regulated in many ways: by calmodulin binding, dimer formation

Address correspondence and reprint requests to: Dr. J. Brice Weinberg, VA and Duke University Medical Centers, Division of Hematology-Oncology, 508 Fulton Street, Durham, NC 27705, U.S.A. Phone: (919)286-6833; Fax: (919)286-6891; E-mail: brice@acpub.duke.edu (the functional enzyme exists as a dimer), substrate (L-arginine) depletion, substrate recycling (L-citrulline to L-arginine), tetrahydrobiopterin availability, endproduct inhibition (NO interaction with NOS heme), phosphorylation, and subcellular localization. Important NOS co-factors include FAD, FMN, NADPH, tetrahydrobiopterin, and calmodulin-calcium. For NOS2, calmodulin is tightly bound to protein, making it relatively resistant to inhibition by calcium chelators. The enzymatic activity of NOS can be markedly influenced by levels of tetrahydrobiopterin-depleting cellular tetrahydrobiopterin by inhibitors of GTP cyclohydrolase I, sepiapterin reductase, and dihydrofolate reductase reduces NOS activity (7). Cytokines and lipopolysaccharide (LPS) can enhance tetrahydrobiopterin production $(8,9)$. Heme is a critical component of NOS; NO can act as a feedback inhibitor of NOS activity by binding to, and perhaps oxidizing, the iron in heme $(10,11)$.

Much of the work that has examined NOS2 regulation and NO production by mononuclear phagocytes has been done using mouse or rat peritoneal macrophages, or mouse neoplastic macrophage cell lines derived from tissue macrophages. Evidence was established that macrophage-elaborated NO played major roles in mediating anti-cancer, anti-microbial, and proinflammatory effects of macrophages. In the late 1980 s and early 1990s, investigators attempting to extend the rodent results to human mononuclear phagocytes had difficulty demonstrating high-level NOS2 expression and NO production by these human cells (see refs. 12,13 for reviews), even though researchers had shown that humans can produce NO (and the NO metabolites nitrite/nitrate) after infection or after treatment with interleukin-2 (IL-2) (14-17), and that 


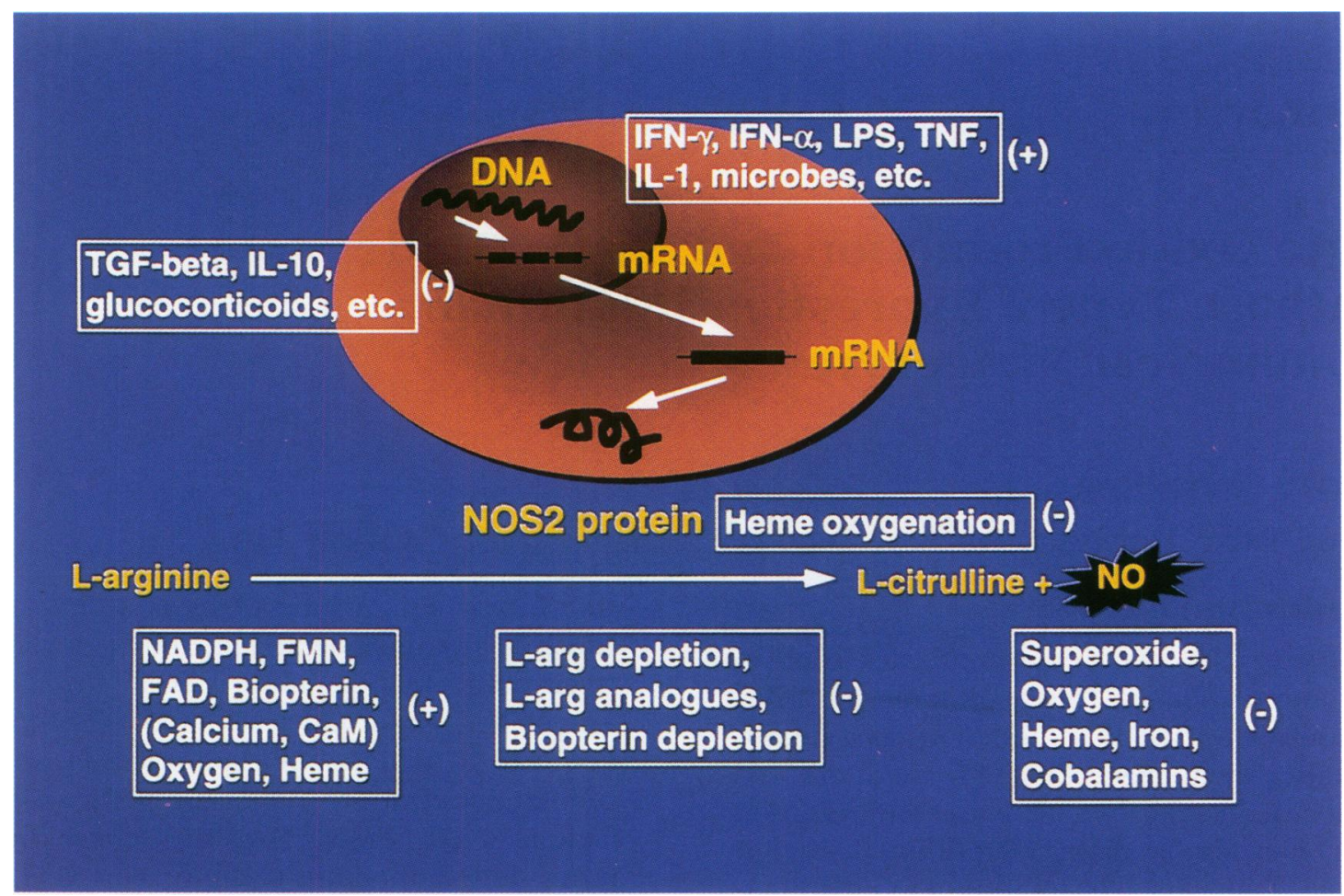

Fig. 1. Expression of NOS2 and production of NO by mononuclear phagocytes. Transcription of NOS2 mRNA can be enhanced $(+)$ by certain cytokines, growth factors, and microbial components. Transcription and translation of NOS2 mRNA can be diminished (-) by glucocorticoids, TGF-beta, various cytokines, and iron. The enzyme NOS converts Larginine to nitric oxide and L-citrulline, and it requires NADPH, biopterin, FMN, FAD, oxygen, and heme for activity. Depletion of L-arginine or tetrahy-

this NO was derived from L-arginine (15). With improvements in techniques and reagents [e.g., more sensitive assays for NO-related products, specific anti-NOS2 antibodies, and reverse transcriptase-polymerase chain reaction (RT-PCR) techniques], recent studies have more convincingly documented NOS 2 protein and mRNA expression and NO production by mononuclear phagocytes with certain treatments in vitro and in vivo and in a variety of disease states. In several instances, there are no adequate explanations for the varying results from apparently identical experiments done in different research laboratories, with some showing induction of NO production and NOS2 expression and some not, despite using comparable techniques. Whereas most rat and mouse studies are done with genetically homogenous (often inbred and syngeneic) animals, human studies involve genetically heterogenous subjects. Genetic polymorphisms in drobiopterin diminishes activity. L-arginine analogues such as $\mathrm{N}^{\mathrm{G}}$-monomethyl-L-arginine block enzyme activity. Nitric oxide can inhibit NOS activity by interacting with and perhaps oxidizing the enzyme's heme group. Superoxide and oxygen rapidly diminish nitric oxide activity by oxidizing it. Iron, heme, and cobalamins can blunt nitric oxide's activity by binding nitric oxide to their iron or cobalt. Abbreviations: IFN, interferon; IL, interleukin; CaM, calmodulin; L-arg, L-arginine.

certain cytokine genes or in the NOS2 gene could explain some of the variability among different laboratories. Kun et al. have identified a single nucleotide polymorphism in the NOS2 promoter region (in a IFN- $\gamma$ response element) that is associated with protection from severe malaria (18). They have postulated that those with this polymorphism will have higher levels of transcription of NOS2 in response to stimuli than those with the wild-type gene.

Bioassays have been used by some to determine NO production by human mononuclear phagocytes. These have included assays demonstrating inhibition of platelet aggregation, induction of smooth muscle relaxation, or inhibition of cellular proliferation. Some of these bioassays have been coupled with use of NO quenchers such as hemoglobin, or NOS enzyme inhibitors such as L-arginine analogues [e.g., $\mathrm{N}^{\mathrm{G}}$-monomethyl-L-arginine (NMMA)] to determine spec- 
ificity of the effects. Certain problems may arise in chemically measuring $\mathrm{NO}$ and its metabolites (19). In oxygen-containing environments, NO is converted within seconds to nitrite and nitrate (in approximate equimolar concentrations) (20). Chemiluminescence measurements of NO in solution might underestimate amounts of NO formed because of the short-lived nature of the molecule. Nitrite and nitrate are generally stable and unreactive at neutral $\mathrm{pH}$. Nitrite can be relatively easily measured spectrophotometrically using the Griess reaction $(21,22)$. Nitrate is generally measured after conversion of nitrate to nitrite with nitrate reductase, and subsequent use of the Griess reaction. In the presence of hemoglobin (and other heme-containing compounds), nitrite is converted to nitrate; thus, studies in which only nitrite is measured may underestimate the amount of NO formed. NO may react with low- and high-molecular-weight thiols, and thus not be measured in the conventional measurements of nitrite/nitrate (20). NO can react with superoxide to form peroxynitrite. This, in turn, can result in nitrotyrosine formation with free tyrosine or with tyrosine-containing proteins (23); this too would not be measured in conventional assays of nitrite/nitrate. Some tissue culture media (e.g., most preparations of RPMI-1640) contain added nitrate, and sera used in tissue culture may contain variable amounts of nitrite/nitrate. Thus, unless investigators measure nitrite/nitrate content of their cell-free culture medium with serum, errors may occur.

Nevertheless, in vitro studies in which investigators have carefully measured NO (by chemiluminescence or amperometrically), nitrite, or nitrite + nitrate generally appear to have accurately reflected cellular NO production. In some of the studies discussed, cells or tissues taken from subjects have been used to measure NOS enzyme activity or NOS2 antigen content as assessed by immunofluorescence-immunoperoxidase techniques or by immunoblot analyses. Because of potential problems with nonspecificity of the antibodies in some of the studies, immunoblot assays (which give not only semi-quantitative positive or negative results but also antigen molecular mass) have yielded more convincing information.

The purpose of this report is to review the literature regarding human mononuclear phagocytes and NOS 2 expression and NO production. I discuss studies in which human blood and tissue cells have been explanted and examined either with no in vitro manipulation or after in vitro culture and treatment. I do not include studies in which investigators measured only serum, plasma, gas, or tissue fluid NO or NO metabolites. Some studies of blood cells have used purified monocytes, while others have used mononuclear cells (MNC-monocytes, lymphocytes, and variable numbers of platelets) isolated by centrifugation over ficoll-Hypaque. Some of the studies have used immune assays to identify cells (e.g., anti-CD14 or anti-CD68 antibodies to identify mononuclear phagocytes), while others have not. Most have assumed that monocytes in the MNC were the likely sources of NO, but investigators have also reported NO production and NOS2 expression by human Epstein-Barr virus (EBV)-transformed B lymphocyte cell line cells (24) and transformed human $\mathrm{T}$ cell line cells (25). Furthermore, normal B and T lymphocytes have been noted to express NOS3 mRNA as detected by RT-PCR (26). These studies signify that lymphocytes in the MNC fraction might also produce NO. Likewise, there are reports that human platelets contain NOS2 and can produce NO (2729). However, significant levels of NO production by lymphocytes and platelets (compared to mononuclear phagocytes) is unlikely (30). I also discuss reports analyzing tissues taken from humans and analyzed by immunocytology or immunohistology, in situ hybridization, or RT-PCR for NOS2 mRNA expression. Reports of NOS2 expression and NO expression by cells from patients with various clinical disorders are also evaluated.

This review reveals that investigators have clearly documented that human monocytes and tissue macrophages can express NOS2 and produce $\mathrm{NO}$ both in vitro and in vivo under a variety of conditions and in a variety of disease states.

\section{Cytokine Activation of Human Mononuclear Phagocytes for NO Production}

\section{Spontaneous NO Production/NOS2 Expression}

Table 1 summarizes reports analyzing NO production and NOS2 expression in human mononuclear phagocytes. The papers are listed alphabetically by author for sequential years. Most investigators have noted that MNC and mononuclear phagocytes do not spontaneously produce NO or express NOS. However, some have presented evidence of NO production or NOS2 expression in MNC or mononuclear phagocytes 
Table 1. NO production and NOS2 expression analysis in human mononuclear phagocytes ${ }^{a}$

\begin{tabular}{|c|c|c|c|c|c|}
\hline Reference & Cell type & In vitro $R \mathbf{x}$ & Assay & Detected & Comments \\
\hline \multicolumn{6}{|l|}{1989} \\
\hline Salvemini et al. (31) & MNC & None & $\begin{array}{l}\text { Inhibit platelet } \\
\text { aggregation }\end{array}$ & Yes & \\
\hline \multicolumn{6}{|l|}{1990} \\
\hline Cameron et al. (40) & $\begin{array}{l}\text { Alv Mac, Perit } \\
\text { Mac }\end{array}$ & IFN- $\gamma$ & $\begin{array}{l}\text { Nitrite, nitrate, L-Arg } \\
\text { to L-Cit }\end{array}$ & No & $\begin{array}{l}\text { No evidence of NO involvement in } \\
\text { anti-cryptococcal effects }\end{array}$ \\
\hline \multicolumn{6}{|l|}{1991} \\
\hline Denis (4l) & Mo & $\begin{array}{l}\text { Mycobacterium } \\
\text { avium, TNF, } \\
\text { GM-CSF }\end{array}$ & Nitrite & Yes & \\
\hline Sherman et al. (42) & Alv Mac & LPS, IFN- $\gamma$ & Nitrite, L-Cit & Yes & $\begin{array}{l}\text { No increase in nitrite, but increased } \\
\text { L-Cit with IFN- } \gamma \text { treatment }\end{array}$ \\
\hline \multicolumn{6}{|l|}{1992} \\
\hline Harwix et al. (44) & Mo & LPS, IFN- $\gamma$ & Nitrite & No & $\begin{array}{l}\text { No evidence of NO generation in } \\
\text { tumoricidal Mo }\end{array}$ \\
\hline $\begin{array}{l}\text { Hunt and Goldin } \\
\text { (32) }\end{array}$ & Mo & None & Nitrite & Yes & $\begin{array}{l}\text { More in Mo from patients with } \\
\text { alcoholic hepatitis }\end{array}$ \\
\hline $\begin{array}{l}\text { Muñoz-Fernández et } \\
\text { al. (43) }\end{array}$ & Mo & IFN- $\gamma$, TNF & Nitrite & Yes & $\begin{array}{l}\text { Anti-Trypanosomal cruzi activity } \\
\text { inhibited by NMMA }\end{array}$ \\
\hline $\begin{array}{l}\text { Murray and } \\
\text { Teitelbaum (45) }\end{array}$ & Mo & IFN- $\gamma$ & Nitrite & No & $\begin{array}{l}\text { No inhibition of anti-microbial } \\
\text { effect by NMMA; also no NO } \\
\text { production by Mo from patients } \\
\text { receiving IFN- } \gamma \text { in vivo }\end{array}$ \\
\hline $\begin{array}{l}\text { Padgett and Pruett } \\
\text { (46) }\end{array}$ & Mo & $\begin{array}{l}\text { LPS, IFN- } \gamma \text {, } \\
\text { opsonized } \\
\text { zymosan, SEB, } \\
\text { PMA }\end{array}$ & Nitrite & No & \\
\hline \multicolumn{6}{|l|}{1993} \\
\hline Belenky et al. (96) & Mo & fMLP & $\begin{array}{l}\text { Chemotaxis } \\
\text { inhibition by } \\
\text { NMMA }\end{array}$ & Yes & $\begin{array}{l}\text { L-Arg analogues inhibited } \\
\text { chemotaxis to fMLP }\end{array}$ \\
\hline $\begin{array}{l}\text { Ben-Efraim et al. } \\
\text { (47) }\end{array}$ & Perit Mac & LPS, PMA, IND & Nitrite & No & \\
\hline Bermudez (48) & Mo & $\begin{array}{l}\text { TNF, GM-CSF, } \\
\text { IFN- } \gamma \text {, Listeria } \\
\text { monocytogenes, } \\
\text { M. avium }\end{array}$ & Nitrite & No & $\begin{array}{l}\text { No inhibition of anti-microbial } \\
\text { effect by NMMA or arginase }\end{array}$ \\
\hline $\begin{array}{l}\text { Condino-Neto et al. } \\
\text { (151) }\end{array}$ & MNC & None & $\begin{array}{l}\text { Inhibit platelet } \\
\text { aggregation }\end{array}$ & Yes & $\begin{array}{l}\text { Inhibition blocked by an L-Arg } \\
\text { analogue }\end{array}$ \\
\hline Keller et al. (49) & BM-derived Mac & $\begin{array}{l}\text { IL-3, M-CSF, } \\
\text { GM-CSF }\end{array}$ & Nitrite & No & $\begin{array}{l}\text { Tumoricidal effect not inhibited by } \\
\text { NMMA }\end{array}$ \\
\hline Kobzik et al. ( 1111$)$ & Alv Mac & None & $\begin{array}{l}\text { Histology with } \\
\text { diaphorase and } \\
\text { anti-NOS2 Ab }\end{array}$ & Yes & $\begin{array}{l}\text { More expression in those from } \\
\text { patient with inflammation }\end{array}$ \\
\hline $\begin{array}{l}\text { Martin and Edwards } \\
\quad \text { (34) }\end{array}$ & Mo & Culture & Nitrite & Yes & $\begin{array}{l}\text { Tumoricidal effect inhibited by } \\
\text { NMMA }\end{array}$ \\
\hline $\begin{array}{l}\text { Middleton et al. } \\
\text { (33) }\end{array}$ & MNC & None & $\begin{array}{l}\text { Smooth muscle } \\
\text { relaxation }\end{array}$ & Yes & $\begin{array}{l}\text { Relaxation inhibited by NMMA, Hb, } \\
\text { or methylene blue }\end{array}$ \\
\hline Naotunne et al. (92) & MNC & Malaria extracts & $\begin{array}{l}\text { Inhibition of anti- } \\
\text { malarial action by } \\
\text { NMMA }\end{array}$ & Yes & $\begin{array}{l}\text { Inhibition of MNC anti-malarial } \\
\text { effects by NMMA }\end{array}$ \\
\hline
\end{tabular}


Table 1. NO production and NOS2 expression analysis in human mononuclear phagocytes ${ }^{a}(\operatorname{cont})$

\begin{tabular}{|c|c|c|c|c|c|}
\hline Reference & Cell type & In vitro $\mathbf{R x}$ & Assay & Detected & Comments \\
\hline Petit et al. (36) & Mo & None & Nitrite & No & $\begin{array}{l}\text { No inhibition of anti-tumor activity } \\
\text { by L-Arg analogues }\end{array}$ \\
\hline $\begin{array}{l}\text { Sakai and Milstien } \\
\quad(50)\end{array}$ & MNC & LPS, IFN- $\gamma$ & Nitrite & No & $\begin{array}{l}\text { No effect of adding } \mathrm{BH}_{4} \text { or } \\
\text { sepiapterin }\end{array}$ \\
\hline $\begin{array}{l}\text { Schneemann et al. } \\
\text { (51) }\end{array}$ & Mo & $\begin{array}{l}\text { LPS, IFN- } \gamma, \text { GM- } \\
\text { CSF, TNF, IL-2, } \\
\text { PPD, Listeria, } \\
\text { Moraxella }\end{array}$ & $\begin{array}{l}\text { Nitrite, L-Arg } \\
\text { consumption, L-Cit } \\
\text { production, NOS } \\
\text { activity }\end{array}$ & No & No benefit from adding $\mathrm{BH}_{4}$ \\
\hline $\begin{array}{l}\text { Wickramasinghe } \\
\text { and Hasan (35) }\end{array}$ & BM Mac & None & Nitrite & Yes & Inhibited by NMMA \\
\hline \multicolumn{6}{|l|}{1994} \\
\hline $\begin{array}{l}\text { Barnewall and } \\
\quad \text { Rikihisa (52) }\end{array}$ & Mo, THP-1 & $\begin{array}{l}\text { IFN- } \gamma, \text { Ehrlichia } \\
\text { chaffeensis, PMA }\end{array}$ & Nitrite & No & $\begin{array}{l}\text { Monocyte-mediated anti-Ehrlichia } \\
\text { effects not dependent on NO } \\
\text { production }\end{array}$ \\
\hline $\begin{array}{l}\text { Beckman et al. } \\
\quad \text { (121) }\end{array}$ & $\begin{array}{l}\text { Arterial } \\
\text { atheromata } \\
\text { Mac }\end{array}$ & None & $\begin{array}{l}\text { Immunohistology for } \\
\text { nitrotyrosine }\end{array}$ & Yes & $\begin{array}{l}\text { Nitrotyrosine as evidence of } \\
\text { peroxynitrite (and NO) formation } \\
\text { in situ }\end{array}$ \\
\hline Bo et al. (144) & Brain Mac & None & RT-PCR & Yes & $\begin{array}{l}\text { NOS } 2 \text { mRNA noted in brain tissue } \\
\text { from patients with multiple } \\
\text { sclerosis }\end{array}$ \\
\hline De Maria et al. (97) & Mo & $\begin{array}{l}\text { Anti-CD69 Ab, } \\
\text { LPS, IFN- } \gamma\end{array}$ & $\begin{array}{l}\text { Nitrite and nitrate, } \\
\text { tumor cytotoxicity }\end{array}$ & Yes & $\begin{array}{l}\text { Inhibited by NMMA; LPS and IFN- } \gamma \\
\text { without effect }\end{array}$ \\
\hline Dumarey et al. (91) & MNC & $\begin{array}{l}\text { Live } M . \text { avium, } \\
\text { LPS, IFN- } \gamma \text {, } \\
\text { TNF }\end{array}$ & Nitrite and nitrate & Yes & $\begin{array}{l}\text { Inhibited by NMMA; only a certain } \\
\text { strain effective }\end{array}$ \\
\hline Essery et al. (52) & MNC & LPS, SEB & Nitrite & Yes & \\
\hline Gyan et al. (54) & MNC & IFN- $\gamma$ & Nitrite & Yes & $\begin{array}{l}\text { Nitrite production and anti-malarial } \\
\text { activity inhibited by NMMA }\end{array}$ \\
\hline Haddad et al. (113) & Alv Mac & None & $\begin{array}{l}\text { Immunocytology, } \\
\text { immunohistology }\end{array}$ & Yes & $\begin{array}{l}\text { Nitrotyrosine as evidence of } \\
\text { peroxynitrite (and NO) formation } \\
\text { in situ in patients with acute } \\
\text { lung injury }\end{array}$ \\
\hline Kolb et al. (79) & Mo & IL-4, IFN- $\gamma$ & Nitrite & Yes & $\begin{array}{l}\text { Sequential IL- } 4 \text { then IFN- } \gamma \\
\text { treatment increased nitrite; } \\
\text { inhibited by NMMA }\end{array}$ \\
\hline Leibovich et al. (55) & Mo & LPS & Nitrite and nitrate & Yes & Inhibited by L-Arg analogues \\
\hline $\begin{array}{l}\text { Martin and Edwards } \\
\quad(56)\end{array}$ & Mo & IFN- $\gamma$ & Nitrite & Yes & $\begin{array}{l}\text { Increase with time in culture; no } \\
\text { augmentation by IFN- } \gamma\end{array}$ \\
\hline Mautino et al. (80) & Mo & IL-4 & Nitrite & Yes & $\begin{array}{l}\text { Heterogenous production; allergic } \\
\text { subjects higher; inhibited by } \\
\text { NMMA }\end{array}$ \\
\hline $\begin{array}{l}\text { Paul-Eugene et al. } \\
\qquad(81)\end{array}$ & MNC & IL-4 & Nitrite & Yes & $\begin{array}{l}\text { NMMA inhibited IL-4-induced IgE } \\
\text { production }\end{array}$ \\
\hline $\begin{array}{l}\text { Pietraforte et al. } \\
\quad \text { (94) }\end{array}$ & Mo & gpl20 & $\begin{array}{l}\text { Nitrite and spin } \\
\text { trapping (DMPO) }\end{array}$ & Yes & Inhibited by L-Arg analogues \\
\hline Reiling et al. (60) & $\begin{array}{l}\text { Mo, U937, } \\
\text { THP-1, } \\
\text { Mono-Mac6 }\end{array}$ & LPS, IFN- $\gamma$ & RT-PCR & Yes & $\begin{array}{l}\text { NOS } 3 \text { mRNA in "resting" Mo and } \\
\text { leukemia cells, and NOS } 2 \text { mRNA } \\
\text { in treated Mo }\end{array}$ \\
\hline $\begin{array}{l}\text { Thomsen et al. } \\
\text { (136) }\end{array}$ & $\begin{array}{l}\text { Gynecological } \\
\text { cancer MNC }\end{array}$ & None & $\begin{array}{l}\text { L-Arg to L-Cit, } \\
\text { immunohistology, } \\
\text { immunoblot }\end{array}$ & No & $\begin{array}{l}\text { NOS2 in tumor cells, but not in } \\
\text { leukocytes }\end{array}$ \\
\hline
\end{tabular}


Table 1. NO production and NOS2 expression analysis in human mononuclear phagocytes ${ }^{a}\left(\right.$ cont.) $^{2}$

\begin{tabular}{|c|c|c|c|c|c|}
\hline Reference & Cell type & In vitro $\mathbf{R x}$ & Assay & Detected & Comments \\
\hline Tracey et al. (112) & Alv Mac & None & Immunohistology & Yes & $\begin{array}{l}\text { NOS2 antigen in Mac from patients } \\
\text { with bronchiectasis and } \\
\text { pneumonia }\end{array}$ \\
\hline Tufano et al. (95) & Mo & $\begin{array}{l}\text { Yersinia } \\
\quad \text { enterocolitica } \\
\quad \text { porins }\end{array}$ & Nitrite & Yes & Some LPS contamination in porin \\
\hline Zembala et al. (57) & Mo & $\begin{array}{l}\text { Selected tumor } \\
\text { cells, IL- } 2, \text { LPS, } \\
\text { TNF, IFN- } \gamma\end{array}$ & Nitrite & Yes & $\begin{array}{l}\text { Inhibited by L-Arg analogues; no } \\
\text { effect of IL- } 2 \text {, LPS, TNF, IFN- } \gamma\end{array}$ \\
\hline \multicolumn{6}{|l|}{1995} \\
\hline Bagasra et al. (145) & Brain Mac & None & $\begin{array}{l}\text { Northern blot; RT-in } \\
\text { situ-PCR, } \\
\text { immunohistology }\end{array}$ & Yes & $\begin{array}{l}\text { NOS } 2 \text { mRNA and nitrotyrosine in } \\
\text { Mac of patients with multiple } \\
\text { sclerosis and absent in "control" } \\
\text { brains }\end{array}$ \\
\hline $\begin{array}{l}\text { Bose and Farnia } \\
\text { (59) }\end{array}$ & MNC & IFN- $\gamma$, TNF, IL- 1 & Nitrite & Yes & \\
\hline $\begin{array}{l}\text { Bukrinsky et al. } \\
\text { (61) }\end{array}$ & Mo & $\begin{array}{l}\text { M-CSF, HIV-1 } \\
\text { infection, } \\
\text { IFN- } \gamma, \text { LPS; } \\
\text { co-culture with } \\
\text { astroglial cells }\end{array}$ & $\begin{array}{l}\text { Nitrite, RT-PCR, EPR } \\
\text { (Fe-DETC) }\end{array}$ & Yes & $\begin{array}{l}\text { All cells cultured with M-CSF, and } \\
\text { then infected/treated with other } \\
\text { additives; inhibited by NMMA }\end{array}$ \\
\hline Chu et al. (37) & Alv Mac & $\begin{array}{l}\text { IFN- } \gamma, \text { IL-1, TNF, } \\
\quad \text { IL-6 }\end{array}$ & RT-PCR & Yes & $\begin{array}{l}\text { Structural diversity in the } 5^{\prime} \\
\text { untranslated region of mRNA }\end{array}$ \\
\hline $\begin{array}{l}\text { Criado-Jimenez et } \\
\text { al. (106) }\end{array}$ & MNC & None & Nitrite & Yes & $\begin{array}{l}\text { Higher activity cells from cirrhosis } \\
\text { patients; L-Arg analogue } \\
\text { inhibited }\end{array}$ \\
\hline Laffi et al. (107) & Mo & None & $\begin{array}{l}\text { L-Arg to L-Cit, } \\
\text { inhibition of } \\
\text { platelet aggregation }\end{array}$ & Yes & $\begin{array}{l}\text { Higher activity in cells from } \\
\text { patients with cirrhosis; inhibited } \\
\text { by L-Arg analogues }\end{array}$ \\
\hline Kim et al. (153) & Mo & LPS & Nitrite, nitrate & Yes & $\begin{array}{l}\text { Higher NO production in PBMC } \\
\text { from trauma patients; some } \\
\text { reduction of NO production by } \\
\text { IL-13 }\end{array}$ \\
\hline Kooy et al. (114) & Alv Mac & None & $\begin{array}{l}\text { Immunohistology for } \\
\text { nitrotyrosine }\end{array}$ & Yes & $\begin{array}{l}\text { Nitrotyrosine as evidence of } \\
\text { peroxynitrite (and NO) formation } \\
\text { in situ in patients with acute } \\
\text { lung injury }\end{array}$ \\
\hline Kumar et al. (117) & Mo & $\begin{array}{l}\text { LPS, PPD, PMA, } \\
\text { latex spheres }\end{array}$ & Nitrite, L-Cit & Yes & $\begin{array}{l}\text { Higher in cells from patients with } \\
\text { tuberculosis pretreatment }\end{array}$ \\
\hline $\begin{array}{l}\text { Lecoanet-Henchoz } \\
\text { et al. (82) }\end{array}$ & Mo & $\begin{array}{l}\text { sCD23, } \\
\text { anti-CD11b, } \\
\text { anti-CD11c }\end{array}$ & Nitrite, nitrate & Yes & Inhibited by L-Arg analogue \\
\hline Masini et al. (108) & Mo & None & $\begin{array}{l}\text { L-Arg to L-Cit, } \\
\text { inhibition of } \\
\text { platelet aggregation }\end{array}$ & Yes & $\begin{array}{l}\text { Higher in Mo from patients with } \\
\text { cirrhosis; inhibited by NMMA }\end{array}$ \\
\hline $\begin{array}{l}\text { Paul-Eugene et al. } \\
\text { (84) }\end{array}$ & PBMC & IL-4 & $\begin{array}{l}\text { Inhibition of IL-4- } \\
\text { induced increase in } \\
\text { IL-4 and SCD23 } \\
\text { production }\end{array}$ & Yes & Phenomenon blocked by NMMA \\
\hline $\begin{array}{l}\text { Paul-Eugene et al. } \\
\text { (83) }\end{array}$ & Mo & $\begin{array}{l}\text { IL-4, IgE-immune } \\
\text { complexes }\end{array}$ & Nitrite & Yes & Inhibited by NMMA \\
\hline $\begin{array}{l}\text { Paul-Eugene et al. } \\
\quad(85)\end{array}$ & Mo & $\begin{array}{l}\text { IL-4, sCD23, } \\
\text { IFN- } \gamma\end{array}$ & Nitrite; L-Cit & Yes & $\begin{array}{l}\text { Inhibited by L-Arg analogue or } \\
\text { anti-CD23 }\end{array}$ \\
\hline
\end{tabular}


Table 1. NO production and NOS2 expression analysis in human mononuclear phagocytes ${ }^{a}$ (cont.)

\begin{tabular}{|c|c|c|c|c|c|}
\hline Reference & Cell type & In vitro $\mathbf{R x}$ & Assay & Detected & Comments \\
\hline $\begin{array}{l}\text { Perez-Mediavilla et } \\
\text { al. (98) }\end{array}$ & MNC & ECM peptides & $\begin{array}{l}\text { Nitrite; } \\
\quad \text { immunocytology }\end{array}$ & Yes & Inhibited by NMMA \\
\hline Sakurai et al. (128) & Synovial Mac & None & $\begin{array}{l}\text { Nitrite, } \\
\text { immunohistology, } \\
\text { immunoblot, RT- } \\
\text { PCR }\end{array}$ & Yes & $\begin{array}{l}\text { RA and inflammatory osteoarthritis } \\
\text { patients; inhibited by L-Arg } \\
\text { analogue }\end{array}$ \\
\hline Siedlar et al. (58) & Mo & DeTa tumor cells & Nitrite & Yes & $\begin{array}{l}\text { DeTa tumor-induced nitrite } \\
\text { formation blocked by antibodies } \\
\text { against MHC class I or II, CD } 44 \text {, } \\
\text { LFA-3 (CD58), VLA- } \beta 1 \text { (CD29) }\end{array}$ \\
\hline $\begin{array}{l}\text { Thomsen et al. } \\
\text { (134) }\end{array}$ & $\begin{array}{l}\text { Breast cancer } \\
\quad \text { Mac }\end{array}$ & None & $\begin{array}{l}\text { Anti-NOS } 2 \mathrm{Ab} \\
\text { immunocytology, } \\
\text { nitrite and nitrate, } \\
\text { L-Arg to L-Cit }\end{array}$ & Yes & $\begin{array}{l}\text { NOS2 associated with CD68+ Mac } \\
\text { by immunohistology }\end{array}$ \\
\hline $\begin{array}{l}\text { Vouldoukis et al. } \\
\text { (87) }\end{array}$ & Mo & $\begin{array}{l}\text { Anti-CD23 Ab, } \\
\text { IgE-IC, IL-4, } \\
\text { IFN- } \gamma\end{array}$ & $\begin{array}{l}\text { Nitrite, immunoblot, } \\
\text { RT-PCR, L-Arg to } \\
\text { L-Cit }\end{array}$ & Yes & Inhibited by NMMA \\
\hline Weinberg et al. (30) & Mo, Perit Mac & $\begin{array}{l}\text { LPS, IFN- } \gamma \text {, TNF, } \\
\text { IL-1, IL-2, IL-4, } \\
\text { GM-CSF, IL-7, } \\
\text { IL-6, VD }{ }_{3} \\
\text { PMA, ConA, } \\
\text { PHA, A23187, } \\
\text { bacteria, } \\
\text { mycobacteria, } \\
\text { HIV-1 }\end{array}$ & $\begin{array}{l}\text { Nitrite, nitrate, } \\
\text { immunocytology, } \\
\text { immunoblot, RT- } \\
\text { PCR, Northern } \\
\text { blot, RNAse } \\
\text { protection, L-Arg } \\
\text { to L-Cit }\end{array}$ & Yes & $\begin{array}{l}\text { Generally low levels (Mac }>\mathrm{Mo} \text { ) } \\
\text { compared to mouse Mac; no } \\
\text { effect of adding } \mathrm{BH}_{4} ; \mathrm{mRNA} \\
\text { detected only by } \mathrm{RT}-\mathrm{PCR}\end{array}$ \\
\hline Wildhirt et al. (126) & Myocardial Mac & None & Immunohistology & Yes & $\begin{array}{l}\text { NOS2 in infarcted myocardium co- } \\
\text { localized with Mac }\end{array}$ \\
\hline Zinetti et al. (64) & MNC, THP-1 & LPS & $\begin{array}{l}\text { Nitrite; NMMA- or } \\
\text { Hb- or Mb- } \\
\text { inhibitable LPS- } \\
\text { induced TNF } \\
\text { secretion and } \\
\text { inhibition of THP-1 } \\
\text { proliferation }\end{array}$ & Yes & $\begin{array}{l}\text { No nitrite production noted, but } \\
\text { indirect evidence of NO } \\
\text { production }\end{array}$ \\
\hline
\end{tabular}

\section{6}

Anstey et al. (138) MNC

None

Buttery et al. (122) Atherosclerotic None plaque Mac

Condino-Neto et al. MNC (65)

Dias-Da-Motta et al. PBMC (154)
Immunoblot, serum and urine nitrite/ nitrate

Immunohistology, immunoblot, in situ hybridization, nitrotyrosine

IFN- $\gamma$ in vivo, LPS in vitro

PMA, zymosan

Nitrite, nitrate, inhibition of platelet aggregation Inhibition of platelet aggregation

Yes

MNC NOS2 expression in normal Tanzanian children; increased NOS2 in asymptomatic and mild malaria; markedly decreased NOS2 in cerebral malaria

Yes Nitrotyrosine as evidence of peroxynitrite (and NO) formation in situ

No Yes

Inhibited by L-Arg analogue; production noted only in presence of SOD; more activity in cells from patients with sickle cell disease

(Continued) 
Table 1. NO production and NOS2 expression analysis in human mononuclear phagocytes ${ }^{a}$ (cont.)

\begin{tabular}{|c|c|c|c|c|c|}
\hline Reference & Cell type & In vitro $\mathbf{R x}$ & Assay & Detected & Comments \\
\hline Dugas et al. (86) & Mo & $\begin{array}{l}\text { Anti-CD23 } \\
\text { antibody }\end{array}$ & $\begin{array}{l}\text { NMMA-induced } \\
\text { inhibition of anti- } \\
\text { CD23 antibody } \\
\text { induced IL-10 } \\
\text { production }\end{array}$ & Yes & \\
\hline Eissa et al. (38) & Alv Mac & None & RT-PCR & Yes & Alternative splicing of mRNA \\
\hline Kashem et al. (66) & Kidney Mac, Mo & IFN- $\gamma$, TNF & $\begin{array}{l}\text { Immunohistology, } \\
\text { RT-PCR }\end{array}$ & Yes & $\begin{array}{l}\text { Assoc with CD68+ Mac in kidneys } \\
\text { with IgA nephropathy and } \\
\text { proliferative glomerulonephritis; } \\
\text { NOS } 2 \text { mRNA expression in } \\
\text { normal Mo treated in vitro with } \\
\text { IFN- } \gamma+\text { TNF }\end{array}$ \\
\hline Liu et al. (63) & $\begin{array}{l}\text { Fetal microglial } \\
\text { cells }\end{array}$ & $\begin{array}{l}\text { IL- } 1, \text { TNF, IFN- } \gamma \text {, } \\
\text { LPS, TGF- } \beta \text {, } \\
\text { IL-10, HIV-1, } \\
\text { gp } 160\end{array}$ & $\begin{array}{l}\text { Nitrite, } \\
\text { immunocytology, } \\
\text { Northern blot, } \\
\text { immunoblot }\end{array}$ & No & \\
\hline $\begin{array}{l}\text { Lopez-Moratalla et } \\
\text { al. (152) }\end{array}$ & Mo & $\begin{array}{l}\text { Peptides from } \\
\text { thyroid } \\
\text { autoantigens }\end{array}$ & Immunocytology & Yes & $\begin{array}{l}\text { NOS2 in freshly isolated Mo from } \\
\text { Grave's; increased activity } \\
\text { induced by in vitro treatment } \\
\text { with peptides from thyroid } \\
\text { autoantigens }\end{array}$ \\
\hline $\begin{array}{l}\text { Magazine et al. } \\
\qquad(100)\end{array}$ & Mo & Morphine & $\begin{array}{l}\text { NO-specific } \\
\text { amperometric } \\
\text { probe }\end{array}$ & Yes & $\begin{array}{l}\text { Inhibited by L-Arg analogues or } \\
\text { naloxone }\end{array}$ \\
\hline McInnes et al. (129) & Synovial Mac & SEB & $\begin{array}{l}\text { Nitrite, RT-PCR, } \\
\text { immunohistology }\end{array}$ & Yes & $\begin{array}{l}\text { NOS2 in synovial Mac and synovial } \\
\text { fibroblasts }\end{array}$ \\
\hline $\begin{array}{l}\text { McLachlan et al. } \\
\text { (99) }\end{array}$ & Mo & $\begin{array}{l}\text { Dehydroepi- } \\
\text { androsterone, } \\
\text { LPS }\end{array}$ & Nitrite & Yes & \\
\hline $\begin{array}{l}\text { Nicholson et al. } \\
\text { (118) }\end{array}$ & Alv Mac & None & $\begin{array}{l}\text { Immunohistology, } \\
\text { immunoblot, } \\
\text { RT-PCR }\end{array}$ & Yes & $\begin{array}{l}\text { Increased in cells from patients } \\
\text { with tuberculosis }\end{array}$ \\
\hline Singer et al. (140) & Colonic Mac & None & $\begin{array}{l}\text { Immunohistology for } \\
\text { NOS2 and } \\
\text { nitrotyrosine, } \\
\text { RT-PCR }\end{array}$ & Yes & $\begin{array}{l}\text { Found only in inflammatory } \\
\text { mucosal areas in patients with } \\
\text { ulcerative colitis, Crohn's disease, } \\
\text { and diverticulitis }\end{array}$ \\
\hline St. Clair et al. (67) & Mo, MNC & LPS, IFN- $\gamma$ & $\begin{array}{l}\text { Nitrite, nitrate, } \\
\text { immunoblot, L-Arg } \\
\text { to L-Cit }\end{array}$ & Yes & $\begin{array}{l}\text { Increased L-Arg to L-Cit activity and } \\
\text { NOS } 2 \mathrm{Ag} \text { in freshly isolated cells } \\
\text { from patients with RA; increased } \\
\text { responsiveness of MNC of RA } \\
\text { patients to IFN- } \gamma \text { in vitro; } \\
\text { inhibited by NMMA }\end{array}$ \\
\hline Stefano et al. (102) & Mo & $\begin{array}{l}\text { Anandamide } \\
\text { (tetrahydro- } \\
\text { cannabinol } \\
\text { derivative) }\end{array}$ & $\begin{array}{l}\text { NO-specific } \\
\text { amperometric } \\
\text { probe }\end{array}$ & Yes & $\begin{array}{l}\text { Inhibited by L-Arg analogues and a } \\
\text { cannabinoid antagonist }\end{array}$ \\
\hline Wang et al. (68) & $\begin{array}{l}\text { Mo; pleural and } \\
\text { peritioneal } \\
\text { Mac }\end{array}$ & LPS & Nitrite & Yes & $\begin{array}{l}\text { More NO production if adherent to } \\
\text { plastic; more NO production } \\
\text { from tissue Mac from patients } \\
\text { with cancer }\end{array}$ \\
\hline Weyand et al. (127) & Arterial Mac & None & Immunohistology & Yes & $\begin{array}{l}\text { NOS2 in intimal Mac in giant cell } \\
\text { arteritis }\end{array}$ \\
\hline
\end{tabular}


Table 1. NO production and NOS2 expression analysis in human mononuclear phagocytes ${ }^{a}\left(\right.$ cont.) $^{2}$

\begin{tabular}{|c|c|c|c|c|c|}
\hline Reference & Cell type & In vitro $\mathbf{R x}$ & Assay & Detected & Comments \\
\hline \multicolumn{6}{|l|}{1997} \\
\hline Amin et al. (69) & $\begin{array}{l}\text { Mo, HL- } 60 \text { cells, } \\
\text { U937 cells }\end{array}$ & TNF, IL-1, LPS & $\begin{array}{l}\text { L-Arg to L-Cit, } \\
\text { immunoblot, } \\
\text { RT-PCR, Northern } \\
\text { blot }\end{array}$ & Yes & $\begin{array}{l}\text { NOS2 mRNA noted, but negative } \\
\text { by immunoblot and L-Arg to } \\
\text { L-Cit assay }\end{array}$ \\
\hline Aubry et al. (88) & Mo & $\begin{array}{l}\text { sCD23, anti- } \\
\text { CD11b, anti- } \\
\text { CD11c }\end{array}$ & $\begin{array}{l}\text { L-Arg to L-Cit, } \\
\text { immunoblot, } \\
\text { RT-PCR }\end{array}$ & Yes & $\begin{array}{l}\text { Inhibited by NMMA; stimulated } \\
\text { expression of NOS3 (NOS2 not } \\
\text { studied) }\end{array}$ \\
\hline Bagasra et al. (62) & Brain Mac & None & $\begin{array}{l}\text { RT-in situ-PCR, } \\
\text { immunohistology }\end{array}$ & No & $\begin{array}{l}\text { Absence of NOS } 2 \text { mRNA and } \\
\text { nitrotyrosine in brains of patients } \\
\text { with AIDS }\end{array}$ \\
\hline Degroot et al. (146) & Brain Mac & None & $\begin{array}{l}\text { Immunohistology; } \\
\text { nitrite }\end{array}$ & Yes & $\begin{array}{l}\text { In brains of patients with multiple } \\
\text { sclerosis, Mac positive for both } \\
\text { NOS2 and "cNOS;" isolated Mac } \\
\text { produced NO }\end{array}$ \\
\hline Eis et al. (150) & Fetal membrane & None & Immunohistology & Yes & $\begin{array}{l}\text { NOS2 in CD14+ fetal membrane } \\
\text { Mac }\end{array}$ \\
\hline $\begin{array}{l}\text { Grabowski et al. } \\
\qquad(130)\end{array}$ & Synovial Mac & None & Immunohistology & Yes & $\begin{array}{l}\text { NOS2 associated chiefly with } \\
\text { CD68+ Mac by immunohistol; } \\
\text { more NOS2 in RA vs. } \\
\text { osteoarthritis; no NOS2 noted in } \\
\text { tissues from normal subjects (hip } \\
\text { fractures) }\end{array}$ \\
\hline Hooper et al. (147) & Brain Mac & None & $\begin{array}{l}\text { Immunohistology, } \\
\text { RT-in situ-PCR }\end{array}$ & Yes & $\begin{array}{l}\text { NOS2 in brain Mac from multiple } \\
\text { sclerosis patients }\end{array}$ \\
\hline Ikeda et al. (14l) & Bowel Mac & None & Immunohistology & Yes & $\begin{array}{l}\text { Increased NOS } 2 \text { expression in } \\
\text { ulcerative colitis }\end{array}$ \\
\hline King et al. (103) & $\begin{array}{l}\text { Mo, U937, } \\
\text { THP-1 }\end{array}$ & Endothelin-1 & $\begin{array}{l}\text { NO-specific } \\
\text { amperometric } \\
\text { probe }\end{array}$ & Yes & Effect blocked by $\mathrm{ET}_{\mathrm{B}}$ antagonist \\
\hline $\begin{array}{l}\text { Lafond-Walker et al. } \\
\qquad(125)\end{array}$ & $\begin{array}{l}\text { Coronary artery } \\
\text { Mac }\end{array}$ & None & $\begin{array}{l}\text { Immunohistology, in } \\
\text { situ hybridization }\end{array}$ & Yes & $\begin{array}{l}\text { Only in accelerated graft } \\
\text { arteriosclerosis in transplanted } \\
\text { hearts; associated with CD68+ } \\
\text { Mac }\end{array}$ \\
\hline Lammas et al. (104) & Mo & ATP, BCG & $\begin{array}{l}\text { Inhibition of Mo or } \\
\text { BCG killing by } \\
\text { L-Arg analogues }\end{array}$ & No & $\begin{array}{l}\text { No inhibition of Mo or BCG killing } \\
\text { by L-Arg analogues }\end{array}$ \\
\hline $\begin{array}{l}\text { McDermott et al. } \\
\text { (115) }\end{array}$ & Alv Mac & None & $\begin{array}{l}\text { Immunohistology for } \\
\text { NOS2 and } \\
\text { nitrotyrosine }\end{array}$ & Yes & $\begin{array}{l}\text { Lung transplant patients with } \\
\text { obliterative bronchiolitis }\end{array}$ \\
\hline $\begin{array}{l}\text { Moilanen et al. } \\
\text { (132) }\end{array}$ & $\begin{array}{l}\text { Foreign body } \\
\text { Mac (joint } \\
\text { prostheses) }\end{array}$ & None & $\begin{array}{l}\text { L-Arg to L-Cit, } \\
\text { immunohistology, } \\
\text { RT-PCR }\end{array}$ & Yes & NOS2 associated with $\mathrm{CD} 68+\mathrm{Mac}$ \\
\hline Myatt et al. (148) & $\begin{array}{l}\text { Placental Mac } \\
\text { (Hofbauer } \\
\text { cells) }\end{array}$ & None & $\begin{array}{l}\text { Immunohistology, } \\
\text { RT-PCR }\end{array}$ & Yes & NOS2 associated with $\mathrm{CD} 14+\mathrm{Mac}$ \\
\hline Nozaki et al. (116) & Alv Mac & BCG & $\begin{array}{l}\text { Immunocytology and } \\
\text { immunoblot for } \\
\text { NOS2 and } \\
\text { nitrotyrosine, } \\
\text { RT-PCR }\end{array}$ & Yes & $\begin{array}{l}\text { Produced by alv Mac from patients } \\
\text { with pulmonary fibrosis after in } \\
\text { vitro challenge with BCG; } \\
\text { NMMA inhibited Mac-mediated } \\
\text { BCG killing }\end{array}$ \\
\hline Polack et al. (70) & Mo & LPS & $\begin{array}{l}\text { NMMA inhibition of } \\
\text { LPS-induced } \\
\text { increased tissue } \\
\text { factor }\end{array}$ & Yes & \\
\hline
\end{tabular}


Table 1. NO production and NOS2 expression analysis in human mononuclear phagocytes ${ }^{a}$ (cont.)

\begin{tabular}{|c|c|c|c|c|c|}
\hline Reference & Cell type & In vitro $\mathbf{R x}$ & Assay & Detected & Comments \\
\hline Saha et al. (71) & PBMC & $\begin{array}{l}\text { Monophosphoryl } \\
\text { lipid A }\end{array}$ & $\begin{array}{l}\text { Nitrite, } \\
\text { immunocytology; } \\
\text { flow cytometry }\end{array}$ & Yes & $\begin{array}{l}\text { Monophosphoryl lipid A stimulated } \\
\text { but LPS did not; inhibited by L- } \\
\text { Arg analogue }\end{array}$ \\
\hline $\begin{array}{l}\text { Schneemann et al. } \\
\quad(90)\end{array}$ & MNC & IL-4, IFN- $\gamma$ & $\begin{array}{l}\text { Nitrite, L-Arg and L- } \\
\text { Cit levels }\end{array}$ & No & \\
\hline Seitzer et al. (93) & $\begin{array}{l}\text { Mo-derived } \\
\text { multinucleated } \\
\text { giant cells }\end{array}$ & $\begin{array}{l}\text { Nippostrongylus br } \\
\quad \text { brasiliensis }\end{array}$ & RT-PCR & Yes & $\begin{array}{l}\text { NOS } 2 \text { mRNA noted in } 15-21 \% \text { of } \\
\text { single giant cells }\end{array}$ \\
\hline Sharara et al. (76) & Mo, MNC & $\begin{array}{l}\text { IFN- } \alpha \text { in vitro } \\
\text { and in vivo }\end{array}$ & $\begin{array}{l}\text { Nitrite, nitrate, } \\
\text { immunoblot, L-Arg } \\
\text { to L-Cit, RT-PCR }\end{array}$ & Yes & $\begin{array}{l}\text { Induction of NOS2 activity, mRNA, } \\
\text { and Ag content by in vitro } \\
\text { treatment of normal Mo, or in } \\
\text { vivo treatment of hepatitis C } \\
\text { patients; correlation of anti-viral } \\
\text { activity of IFN- } \alpha \text { with degree of } \\
\text { NOS2 induction }\end{array}$ \\
\hline Snell et al. (72) & Mo & $\begin{array}{l}\text { Polyribonucleo- } \\
\text { tides, IFN- } \gamma \\
\text { IFN- } \alpha, \text { IL- } 4\end{array}$ & Nitrite & Yes & $\begin{array}{l}\text { No effect of LPS, IFN- } \gamma \text {, IFN- } \alpha \text {, and } \\
\text { IL-4 alone, but potentiation of } \\
\text { polyribonucleotide effect; } \\
\text { inhibited by NMMA }\end{array}$ \\
\hline $\begin{array}{l}\text { ter Steege et al. } \\
\text { (143) }\end{array}$ & Bowel Mac & None & Immunohistology & Yes & $\begin{array}{l}\text { Increased NOS2 and nitrotyrosine } \\
\text { in CD 14/CD68+ Mac celiac } \\
\text { disease }\end{array}$ \\
\hline Vitek et al. (105) & Mo & $\begin{array}{l}\text { Polyinosinic- } \\
\text { polycytidylic } \\
\text { acid and } \\
\text { apolipoprotein } \\
\text { E }\end{array}$ & Nitrite & Yes & $\begin{array}{l}\text { Amyloid beta peptide inhibited the } \\
\text { apolipoprotein-E-induced } \\
\text { increase }\end{array}$ \\
\hline $\begin{array}{l}\text { Vouldoukis et al. } \\
\text { (89) }\end{array}$ & Mo & Anti-CD23 Ab & Nitrite & Yes & $\begin{array}{l}\text { IL-10 and IL-4 inhibited killing of } \\
\text { Leishmania }\end{array}$ \\
\hline Watkins et al. (133) & $\begin{array}{l}\text { Mac around } \\
\text { loosened bone } \\
\text { hip prostheses }\end{array}$ & None & $\begin{array}{l}\text { In situ hybridization, } \\
\text { immunohistology }\end{array}$ & Yes & No NOS2 in synovial cells \\
\hline Wilcox et al. (123) & Vessel Mac & None & $\begin{array}{l}\text { In situ hybridization, } \\
\text { immunohistology }\end{array}$ & Yes & $\begin{array}{l}\text { Mac in atherosclerotic lesions } \\
\text { expressed both NOS2 and NOS1 }\end{array}$ \\
\hline Zarlingo et al. (149) & Placental Mac & None & $\begin{array}{l}\text { Immunohistology, } \\
\text { immunoblot }\end{array}$ & Yes & \\
\hline \multicolumn{6}{|l|}{1998} \\
\hline Ambs et al. (135) & Tumor Mac & None & $\begin{array}{l}\text { L-Arg to L-Cit, } \\
\text { immunohistology } \\
\text { for NOS2 and } \\
\text { nitrotyrosine, } \\
\text { immunoblot, } \\
\text { RT-PCR }\end{array}$ & Yes & $\begin{array}{l}\text { NOS } 2 \text { in tumors (more in } \\
\text { adenomas than in carcinomas), } \\
\text { but low in normal tissue; present } \\
\text { in MNC, tumor cells, and } \\
\text { endothelial cells; nitrotyrosine in } \\
\text { MNC }\end{array}$ \\
\hline $\begin{array}{l}\text { Aymerich et al. } \\
\quad(101)\end{array}$ & Mo & $\beta$-endorphin & Immunohistology & Yes & \\
\hline Furusu et al. (139) & Kidney Mac & None & $\begin{array}{l}\text { Immunohistology, in } \\
\text { situ hybridization }\end{array}$ & Yes & $\begin{array}{l}\text { NOS2 primarily in mesangial cells } \\
\text { and glomerular epithelial cells; } \\
\text { inverse levels of expression of } \\
\text { NOS } 3 \text { and NOS } 2 \text { in the kidneys } \\
\text { with NOS } 2 \text { correlating with } \\
\text { degree of glomerular injury }\end{array}$ \\
\hline Luoma et al. (124) & Arterial Mac & None & Immunohistology & Yes & $\begin{array}{l}\text { NOS2 and nitrotyrosine associated } \\
\text { with Mac }\end{array}$ \\
\hline
\end{tabular}


Table 1. NO production and NOS2 expression analysis in human mononuclear phagocytes ${ }^{a}$ (cont.)

\begin{tabular}{|c|c|c|c|c|c|}
\hline Reference & Cell type & In vitro $\mathbf{R x}$ & Assay & Detected & Comments \\
\hline Majano et al. (109) & Liver MNC & None & $\begin{array}{l}\text { Immunohistology, in } \\
\text { situ hybridization }\end{array}$ & Yes & $\begin{array}{l}\text { In chronic active hepatitis B or C } \\
\text { patients, NOS } 2 \text { protein and } \\
\text { mRNA noted in hepatocytes, } \\
\text { with only mRNA noted in MNC } \\
\text { in hepatitis }\end{array}$ \\
\hline Perkins et al. (131) & Mo, MNC & None & $\begin{array}{l}\text { Immunoblot, } \\
\text { RT-PCR, L-Arg to } \\
\text { L-Cit }\end{array}$ & Yes & $\begin{array}{l}\text { Increased L-Arg to L-Cit activity, } \\
\text { NOS2 Ag, NOS } 2 \text { mRNA in Mo } \\
\text { and MNC from patients with RA; } \\
\text { anti-TNF antibody treatment in } \\
\text { vivo reduced the increased NOS } \\
\text { activity and NOS } 2 \text { Ag expression }\end{array}$ \\
\hline Tunctan et al. (119) & Mo & LPS & $\begin{array}{l}\text { Nitrite; smooth } \\
\text { muscle relaxation }\end{array}$ & Yes & $\begin{array}{l}\text { Increased nitrite production by LPS- } \\
\text { treated cells from normal subjects } \\
\text { but not those from tuberculosis } \\
\text { patients; supernatant media from } \\
\text { LPS-treated cells of tuberculosis } \\
\text { patients had increased smooth } \\
\text { muscle relaxing activity }\end{array}$ \\
\hline Wang et al. (120) & Alv Mac & None & $\begin{array}{l}\text { Flow cytometry, } \\
\text { immunohistology, } \\
\text { nitrite }\end{array}$ & Yes & $\begin{array}{l}\text { Higher NOS } 2 \text { expression and nitrite } \\
\text { production by cells from } \\
\text { tuberculosis patients; nitrite } \\
\text { production correlated } \\
\text { significantly with exhaled NO } \\
\text { concentration }\end{array}$ \\
\hline
\end{tabular}

${ }^{a}$ Citations are listed alphabetically within each year.

Abbreviations: Alv, alveolar; $\mathrm{BH}_{4}$, tetrahydrobiopterin; $\mathrm{BM}$, bone marrow; ConA, concanavalin $\mathrm{A}$; EPR, electron paramagnetic resonance; fMLP, $N$-formyl methionylleucylphenalanine; IND, indomethacin; L-Arg to L-Cit, assay measuring conversion of Larginine to L-citrulline; Mac, macrophage; MNC, mononuclear cell; Mo, monocyte; NMMA, $\mathrm{N}^{\mathrm{G}}$-monomethyl-L-arginine; Perit, peritoneal; PBMC, peripheral blood mononuclear cells; PHA, phytohemagglutin; PMA, phorbol myristate acetate; PPD, purified protein derivative; RA, rheumatoid arthritis; SEB, staphylococcus enterotoxin $B ; D_{3}, 1,25$ dihydroxyvitamin $D_{3}$.

from apparently normal individuals without the need for special treatment in vitro. It is important to note that cell manipulation by preparation with centrifugation, etc., and with culture in plastic vessels with media and sera may in itself "activate" cells. Salvemini et al. showed that human polymorphonuclear leukocytes (PMN) and MNC released a factor that blocked thrombininduced platelet aggregation (31). The inhibition was abrogated by oxyhemoglobin and L-arginine analogues, and was enhanced by superoxide dismutase (SOD). Although they did not measure NO, their data suggested that the inhibiting factor was NO. Hunt and Goldin noted that normal monocytes spontaneously generated nitrite with in vitro culture (32). This nitrite production was stimulated by LPS and inhibited by NMMA. Middleton et al. found that unstimulated human MNC caused relaxation of rat colonic smooth muscle and that this effect was inhibited by NMMA, hemoglobin, or the guanylate synthase inhibitor methylene blue; superoxide dismutase enhanced the relaxing effect (33). Granulocytes had a comparable effect. Martin and Edwards found that, with time in culture, human monocytes had an increase in nitrite production and an increase in tumoricidal effect (34). The nitrite production and tumor cell killing were inhibited by NMMA.

In studies of the effects of ethanol on bone marrow cell growth, Wickramasinghe and Hasan found that human bone marrow macrophages produced low levels of nitrite; this production could be inhibited by NMMA (35). Whereas ethanol inhibited thymidine and leucine incorporation into bone marrow cells, it did not influence nitrite production, and NMMA did not influence the ethanol effect. On the other hand, Petit et al. found that spontaneous monocyte-mediated anti-tumor activity was not inhibited by L-arginine analogues and that tumoristatic monocytes did not produce nitrite (36). 
Using RT-PCR, Chu and associates studied NOS2 mRNA expression in alveolar macrophages from a normal subject (37). NOS2 mRNA was found in untreated, freshly isolated alveolar macrophages that were allowed to adhere to plastic. There was evidence of structural diversity in the $5^{\prime}$ untranslated region of the mRNA, with the use of multiple transcription initiation sites. Eissa et al. showed (using RT-PCR techniques) that normal human alveolar macrophages contained NOS2 mRNA, and that the mRNA showed evidence of extensive alternative splicing (38). They postulated that alternative splicing might function to regulate levels of expression of functional enzyme.

\section{Cytokines, Growth Factors, and Lipopolysaccharide}

Based on experiences using rodent macrophages, investigators have tried to determine if various cytokines and microbial extracts would activate human mononuclear phagocytes for NO production and NOS2 expression. Most have focused on interferon- $\gamma$ (IFN- $\gamma)$, tumor necrosis factor (TNF), and LPS. Even though Granger and colleagues had shown earlier that mouse macrophages required L-arginine for inhibiting growth of Cryptococcus neoformans (39), they reported in 1990 that human alveolar and peritoneal macrophages from normal individuals mediated fungistasis independently of L-arginine metabolism (40). In this study, Cameron and co-workers could find no evidence that these human cells could generate NO or L-citrulline from L-arginine. Treatment of the cells with IFN- $\gamma$ in vitro enhanced fungistasis, but had no effect on Larginine metabolism (40). They also noted that fungistasis was not inhibited by NMMA.

Contrary to the report of Cameron et al., Denis noted that monocyte-derived macrophages (monocytes cultured for 7 days) from normal individuals treated in vitro with TNF and granulocyte macrophage-colony-stimulating factor (GM-CSF) had enhanced ability to restrict growth of virulent Mycobacterium avium and to kill avirulent $M$. avium (41). The killing was inhibited by NMMA. Whereas treatment of the cells with TNF and GM-CSF did not enhance nitrite formation, the treated cells produced nitrite when inoculated with $M$. avium (41). Sherman et al. noted that LPS and IFN- $\gamma$ enhanced nitrite and L-citrulline production by mouse macrophages, but human alveolar macrophages that were treated with LPS and IFN- $\gamma$ produced only L-citrulline (42). However, co-culture with
Pneumocystis carinii caused a slight increase in both nitrite and L-citrulline formation by the human macrophages (42). Muñoz-Fernández et al. demonstrated that human monocytes treated with IFN- $\gamma$, TNF, or IFN- $\gamma+$ TNF had increased ability to destroy Trypanosoma cruzi and increased production of nitrite (43). NMMA inhibited nitrite production, and nitrite production correlated well with the trypanocidal activity.

Subsequently, however, other investigators again reported an inability to detect NO production by human monocytes. Harwix and others showed that cultured monocytes treated with IFN- $\gamma$ and LPS were tumoricidal, but the monocytes did not produce nitrite (44). Murray and Teitelbaum showed that human monocytes treated in vitro with IFN- $\gamma$ displayed antimicrobial effects toward Toxoplasma gondii, Chlamydia psittaci, or Leishmania donovani. But these antimicrobial effects were not modified by NMMA or by depletion of L-arginine from the medium with arginase (45). Normal monocytes did not produce nitrite; likewise treatment of AIDS subjects with IFN- $\gamma$ in vivo or treatment of normal monocytes in vitro with IFN- $\gamma \pm$ LPS in vitro did not render the cells capable of producing nitrite (45). In a similar fashion, Padgett and Pruett found that human monocytes cultured for 2 weeks failed to produce nitrite in vitro (46). Ben-Efraim et al. showed that although human peritoneal macrophages displayed anti-tumor cell activity in vitro, there was no evidence that untreated cells or cells treated with PMA or indomethacin could produce NO (47). Bermudez found that the antimicrobial actions of human monocytes toward M. avium or Listeria monocytogenes were not inhibited by NMMA or arginase, and that TNF, GMCSF, and IFN- $\gamma$ did not cause nitrite production (48). In comparable ways, Keller et al. noted that human bone marrow-derived macrophages (cultured with IL-3, M-CSF, and GM-CSF) were tumoricidal, and that the tumoricidal effect was not inhibited by NMMA (49). Furthermore, they could detect no nitrite generation by the cells.

Sakai and Milstien showed that human MNC did not produce nitrite after treatment with IFN- $\gamma$ and LPS, and that elevating MNC biopterin levels by adding biopterin or sepiapterin did not render the cells capable of making nitrite (50). In a different study, Schneemann et al. found that human mononuclear phagocytes did not produce nitrite, consume L-arginine, produce L-citrulline, or display NOS activity after treatment with LPS, IFN- $\gamma$, GM-CSF, TNF, IL-2, purified protein derivative (PPD), Listeria, or Moraxella 
(51). As Sakai and Milstien had noted, adding biopterin did enable the cells to produce nitrite (50). Barnewell and Rikhisa showed that culture of human monocytes or THP-1 cells with IFN- $\gamma$ and Ehrlichia chaffeensis did not stimulate nitrite production although growth of the Ehrlichia was inhibited by treatment of the cells with IFN- $\gamma$ or phorbol myristate acetate (PMA) (52).

Essery et al. showed that treatment of human MNC with Staphylococcus enterotoxin B augmented nitrite formation (53). Gyan et al. showed that human MNC cultured with IFN- $\gamma$ produced increased amounts of nitrite and inhibited growth of Plasmodium falciparum (54). Furthermore, the anti-parasite effect was partially blocked by NMMA. Leibovich et al. found that treatment of monocytes with LPS stimulated their production of angiogenic activity, and this increase in activity paralleled an increase in production of nitrite and nitrate (55). The production of the angiogenic activity and of nitrite/ nitrate was reduced when cells were cultured in media low in L-arginine, or when cells were cultured with NMMA. Martin and Edwards noted that with increasing time in culture (up to 9 days), there was an increase in monocyte production of nitrite (56). This effect was not altered by IFN- $\gamma$, although IFN- $\gamma$ did augment the monocyte-mediated tumor cytotoxicity. Zembala et al. noted that normal human monocytes cultured with LPS, IFN- $\gamma$, IL-2, and TNF did not produce nitrite, but culture of the monocytes with a human colorectal cell line (DeTa) caused the monocytes to produce nitrite (57). This production was inhibited by L-arginine analogues. The stimulation of nitrite formation by DeTa cells was inhibited by antibodies directed against CD44, CD29 (VLA- $\beta_{1}$ ), CD58 (LFA-3), and MHC class I or II antigen (but not by several other antibodies) (58). Bose and Farnia found that human monocytes treated with IFN- $\gamma$, TNF, and IL-1 (and subsequently "triggered" with LPS) produced nitrite (59). The cells produced higher levels of nitrite with increasing time in culture. Reiling and co-workers demonstrated using RTPCR that untreated human monocytes, THP-1 cells, U937 cells, and Mono-Mac6 cells displayed mRNA for the "constitutive" isoform of NOS. On stimulation with LPS and IFN- $\gamma$, levels of NOS2 mRNA became detectable and cNOS levels diminished (60).

Bukrinsky and associates studied human monocytes after culture for 7 days with M-CSF and then subsequent infection with HIV-1 (61). Uninfected cells produced little or no NO, but those infected with HIV-1 produced significant amounts. Treatment of these cells with LPS or TNF, or co-culture of the cells with astroglial cells further enhanced NO production, and IL-4 or NMMA decreased the production. NO production was assessed by measurement of nitrite and detection by electron paramagnetic resonance (EPR) of NO "trapped" by Fe-DETC. Also, NOS2 mRNA was detected in infected and stimulated monocytes by RT-PCR (61). Bagasra and coworkers did not find NOS2 mRNA or nitrotyrosine in brains of patients with AIDS (62). Liu et al. noted that human microglial cells would not express NOS2 in response to LPS and cytokines, while astrocytes did (63).

Weinberg and co-workers showed that LPS and/or IFN- $\gamma$ induced normal human monocytes and peritoneal macrophages to express low levels of NOS2 mRNA (as detected by RT-PCR) (30). Immunofluorescence and immunoblot analyses demonstrated that IFN- $\gamma$ induced detectable levels of NOS2 antigen. IFN- $\gamma$ and LPS caused peritoneal macrophages to produce nitrite/nitrate, and increased levels of NOS enzymatic activity in both monocytes and macrophages (30). A large number of other agents in various combinations with LPS and IFN- $\gamma$ were tested for ability to induce production of high level nitrite/nitrate production, and none were effective; these included GM-CSF, IL-1，IL-2, IL-4, IL-7, IL-6, 1,25 vitamin $D_{3}, P M A$, the calcium ionophore A23187, and the lectins concanavalin A and phytohemagglutinin. Likewise, live and heatkilled M. avium, M. tuberculosis, L. monocytogenes, Candida albicans, Staphylococcus epidermidis, and HIV-1 did not enhance nitrite/nitrate production. Furthermore, culture in $3 \%$ to $50 \%$ human, dog, or fetal bovine serum (FBS; heated or unheated) did not cause nitrite/nitrate formation. Additions of excess L-arginine, NADPH, sepiapterin, or biopterin did not enable the cells to produce nitrite/nitrate. Also, in experiments mixing lysates of murine and human cells and in experiments using neutralizing antibodies against TGF- $\beta_{1}$, these investigators could show no evidence of an endogenous inhibitor of NOS expression or function in the human monocytes and macrophages (30).

Zinetti and co-workers noted that NMMA, hemoglobin, or myoglobin would inhibit LPS-induced TNF secretion by MNC and THP- 1 cells even though they could detect no evidence of nitrite formation (64). They felt that their work gave evidence that endogenously produced NO modulated TNF production. Condino-Neto et al. studied pa- 
tients with chronic granulomatous disease who had received IFN- $\gamma$ in vivo for 6 months (65). There found no evidence that IFN- $\gamma$ enhanced nitrite/nitrate synthesis by monocytes or neutrophils when tested in vitro for nitrite/nitrate production or for inhibition of platelet aggregation. Kashem et al. demonstrated by immunocytology that treatment of normal monocytes in vitro with a combination of TNF and IFN- $\gamma$ caused expression of NOS2 mRNA (66).

St. Clair and associates showed that freshly isolated monocytes and MNC from patients with active rheumatoid arthritis (RA) (when compared with those of normal subjects) had increased NOS enzyme activity and increased NOS2 antigen expression (immunoblot) (67). When MNC from patients with RA were cultured with IFN- $\gamma$, they had increased production of nitrite/nitrate, whereas those of normal subjects were not altered. NMMA inhibited the NOS activity. Levels of NOS2 enzyme activity and NOS2 antigen in freshly isolated MNC were positively correlated with the severity of arthritis. Wang et al. noted that monocytes and pleural and peritoneal macrophages produced nitrite after in vitro LPS treatment (68). Tissue macrophages from patients with malignancy produced more nitrite than did those from normal individuals. Amin et al. showed that normal monocytes did not express NOS2 antigen or have NOS enzymatic activity (69). However, using RT-PCR, they demonstrated that monocytes expressed NOS2 mRNA. NOS2 mRNA could also be detected by northern blot in monocytes and U937 cells.

Polack et al. noted that NMMA inhibited LPS-induced increased monocyte tissue factor expression, and they deduced that LPS-induced NO played a role in the tissue factor induction (70). Saha and co-workers noted that monophosphoryl lipid A, an LPS derivative with reduced toxicity for animals in vivo, stimulated NO production by PBMC in vitro, whereas LPS did not stimulate (71). This was detected as increased nitrite production, NOS enzyme activity, and NOS2 protein. Snell et al. showed that monocytes treated with the synthetic polyribonucleotide polyinosinic-polycytidylic acid (Poly I:C) or Poly I enhanced production of nitrite (72). This effect was enhanced if the cells had been pretreated with LPS, IFN- $\gamma$, IFN- $\alpha$, or IL- 4 . Nitrite production under these conditions was inhibited by NMMA.

Whereas others had focused on IFN- $\gamma$, Sharara and co-workers demonstrated that IFN- $\alpha$ functioned as an effective activator of hu-
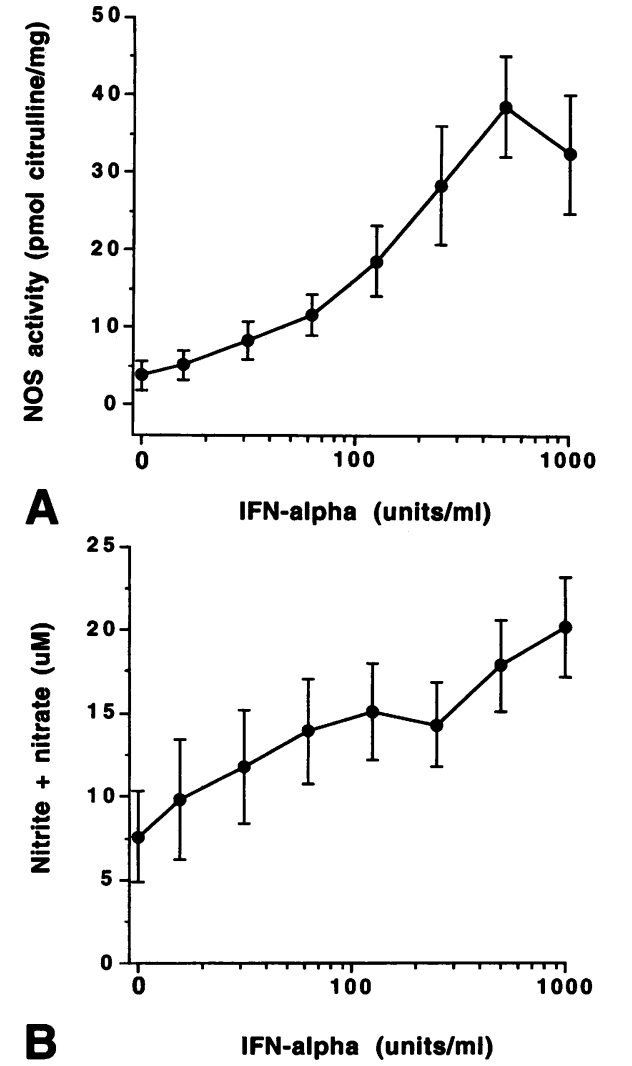

Fig. 2. Enhancement of normal blood monocyte NOS enzyme activity (A) and NO production (B) by treatment with IFN- $\alpha$ in vitro. (A) Purified blood monocytes from eight separate normal individuals were cultured for 3 days with the indicated amounts of IFN- $\alpha$, and analyzed for NOS activity. The points show the mean \pm 1 SEM. (B) Purified blood monocytes from eight separate normal individuals were cultured as noted in $3 \mathrm{~A}$, and then supernatant media samples were assessed for content of nitrite/nitrate. The points show the mean \pm 1 SEM. [Reproduced with permission (76).]

man monocyte NO production and NOS2 expression when used either in vitro or in vivo (76). In rodent macrophages, exogenous IFN- $\alpha$ cannot activate macrophages for NO production (73), but macrophage-synthesized IFN- $\alpha$ can augment NO production in an autocrine fashion (74). Also, Diefenbach et al. noted that macrophage-produced IFN- $\alpha / \beta$ is required for macrophage NOS2 expression (75). Sharara et al. noted that IFN- $\alpha$ induced normal human monocytes in vitro to produce nitrite/nitrate (Fig. 2), to express NOS2 antigen and mRNA, and to display increased NOS enzyme activity (76). NOS activity was inhibited by NMMA. In patients with hepatitis $\mathrm{C}$, administration of IFN- $\alpha$ in vivo increased NOS enzyme activity and caused the appearance 
of NOS2 antigen and mRNA in MNC (Figs. 3 and 4). Cells from hepatitis $C$ patients not receiving IFN- $\alpha$ did not display NOS 2 antigen or mRNA (76). In those patients with hepatitis $C$ receiving IFN- $\alpha$, the degree of induction of NOS 2 correlated significantly with the degree of improvement of their hepatitis. These investigators speculated that enhanced NO production induced by IFN- $\alpha$ or IFN- $\beta$ might account for the development of "autoimmune" illnesses with inflammation similar to rheumatoid arthritis and systemic erythematosus noted in some patients who were treated with IFN- $\alpha$ or IFN- $\beta(77,78)$. The work of Sharara and colleagues (76) appears to be the only study in which investigators have demonstrated activation of human monocytes/MNC for NO production and NOS2 expression both in vitro and in vivo by a defined, purified agent $($ IFN- $\alpha$ ).

\section{IgE, CD23, and Activation of Human Mononuclear Phagocytes for NO Production}

A series of papers have indicated that IgE and CD23 (the low-affinity receptor for IgE) play a role in activating monocytes for NOS2 expression and NO production. Kolb et al. found that monocytes cultured with IL-4 followed by IFN- $\gamma$ treatment produced nitrite, and that this production could be inhibited by NMMA (79). Mautino et al. noted that IL-4 would enhance nitrite production by monocytes, with the degree of enhancement varying among different donors (80). Subjects could be divided into "low-producers" and "high-producers"; IL-4 augmented nitrite production by cells from "low producers," while it decreased production by cells from "high producers." Allergic subjects appeared to have increased production (80). Paul-Eugene et al. showed the IL- 4 stimulated IgE and nitrite production by MNC, and that NMMA inhibited both nitrite and IgE production (81). Lecoanet-Henchoz et al. noted that soluble CD23, or antiCD1 $1 \mathrm{~b}$ and anti-CD11c enhanced nitrite and nitrate formation by human monocytes (82). An L-arginine analogue reduced the NO formation. These investigators suggested that $\mathrm{CDIlb}$ and CD1lc served as receptors for CD23.

In related work, Paul-Eugene et al. showed that ligation of CD23 in monocytes with IgEimmune complexes enhanced nitrite formation, and that this was augmented by IL-4 (83), that NMMA blocked IL-4-induced increased in IL-4 and soluble $\mathrm{CD} 23$ (sCD23) production by peripheral blood mononuclear cells (PBMC) (84), and that IL-4, SCD23, and IFN- $\gamma$ induced nitrite and L-citrulline production by monocytes (85). Dugas and co-workers found that NMMA caused inhibition of anti-CD23 antibody-induced IL-10 expression by monocytes (86). Vouldoukis et al. showed that engagement of CD23 with IgE immune complexes or anti-CD23 antibody caused an increase in nitrite formation and Leishmania killing (87). IgE immune complexes, anti-CD23 antibody, and IFN- $\gamma$ enhanced nitrite formation and the ability of cell lysates to convert L-arginine to L-citrulline. While IL-4 treatment had little or no effect on NOS2 mRNA expression in the monocytes, sequential treatment with IL-4 and anti-CD23 caused expression of NOS2. In general, the abilities to express/produce NOS/NO correlated with abilities to kill parasites (87). Although added TNF did not enhance nitrite formation or Leishmania killing, anti-TNF antibody inhibited NO production and parasite killing; this suggested that endogenously produced TNF was important in this process.

Aubry et al. noted that soluble CD23, anti$\mathrm{CDIlb}$, and anti-CDIlc treatment of monocytes activated them for expression of NOS3 as determined by enzyme activity, immunoblot, and RTPCR (88). NOS activity was inhibited by EGTA and L-arginine analogues. They did not examine NOS2 in this study. Soluble CD23 enhanced monocyte cGMP content and TNF production, and these effects were inhibited by NMMA. Vouldoukis et al. showed that anti-CD23 antibody or IFN- $\gamma$ treatment of monocytes induced nitrite formation and monocyte-mediated killing of Leishmania (89). NMMA inhibited nitrite formation and inhibited Leishmania killing. Recombinant IL-10 or IL-4 inhibited nitrite formation and monocyte-mediated Leishmania killing; combined IL-10 and IL-4 treatment inhibited more than either cytokine alone. In this experimental model, IL-10 was a more potent inhibitor than IL-4.

Contradicting prior studies, Schneeman et al. demonstrated that nitrite generation in IL-4/IFN$\gamma$-treated monocytes likely did not involve the NOS pathway (90). They could not demonstrate any L-arginine consumption or L-citrulline production in these cultures, and synthesis of tetrahydrobiopterin could not be detected. They thought that the nitrite was derived from nitrate in the culture medium or serum, possibly from nitrate reductase activity of IL-4/IFN- $\gamma$. 


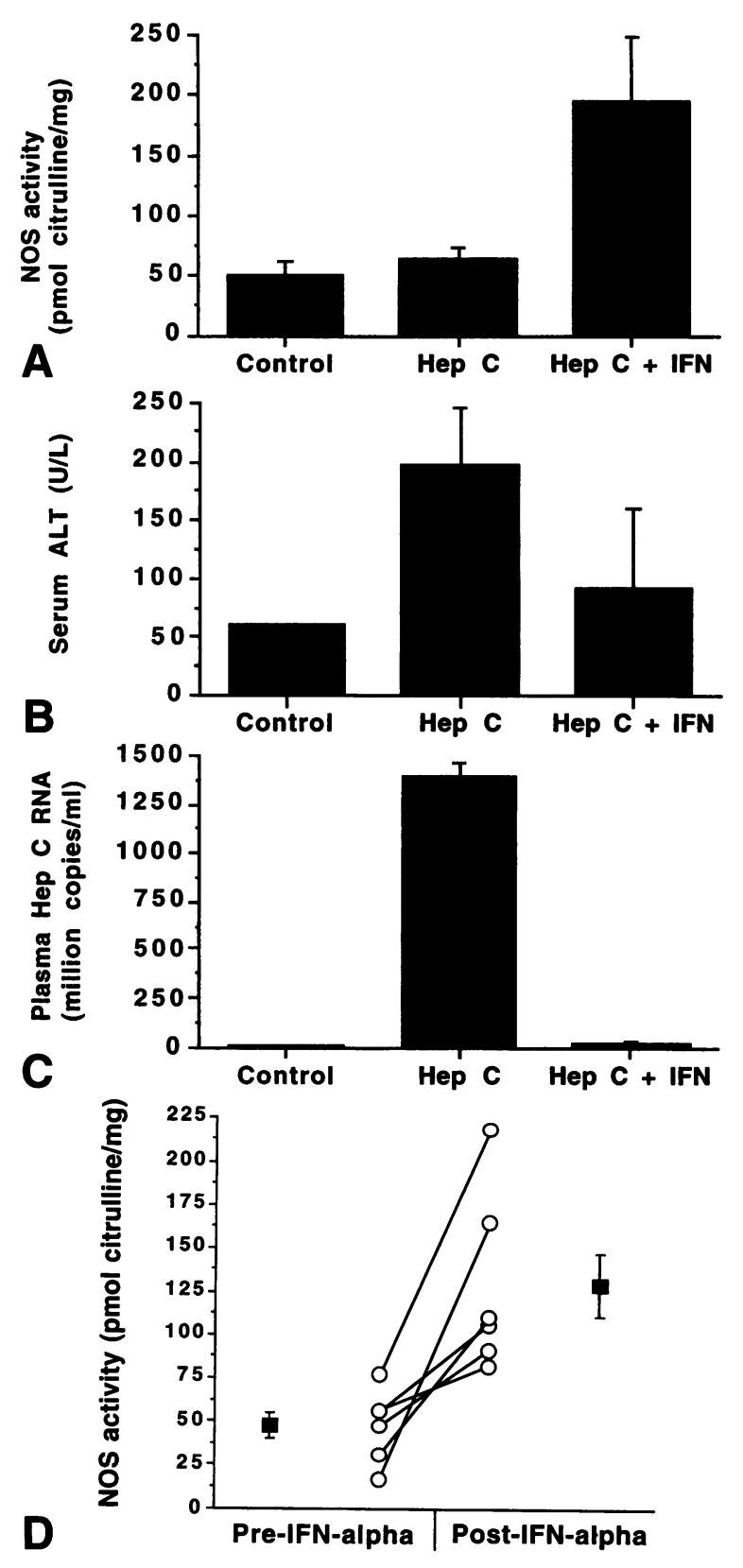

Fig. 3. NOS enzyme activity in extracts of blood mononuclear cells (A), serum alanine aminotransferase (ALT) (B), plasma hepatitis C RNA levels (C), and NOS enzyme activity before and after IFN- $\alpha$ treatment (D). The bars show the mean + 1 SEM for samples taken from the different subject groups. Control, normal control subjects; Hep C, patients with hepatitis C not on therapy; Hep C + IFN, patients with hepatitis $C$ on IFN- $\alpha$ therapy. For NOS measurements, $n=9$ for control, 18 for Hep C, and 15 for Hep C + IFN; for serum ALT, $n=15$; and for plasma hepatitis $C$ RNA, $n=4$. In $\mathrm{D}$, the lines connect the values from an individual patient's samples pre-IFN- $\alpha$ and postIFN- $\alpha$ therapy. The solid squares show the means and I SEM of the groups. [Reproduced with permission (76).]

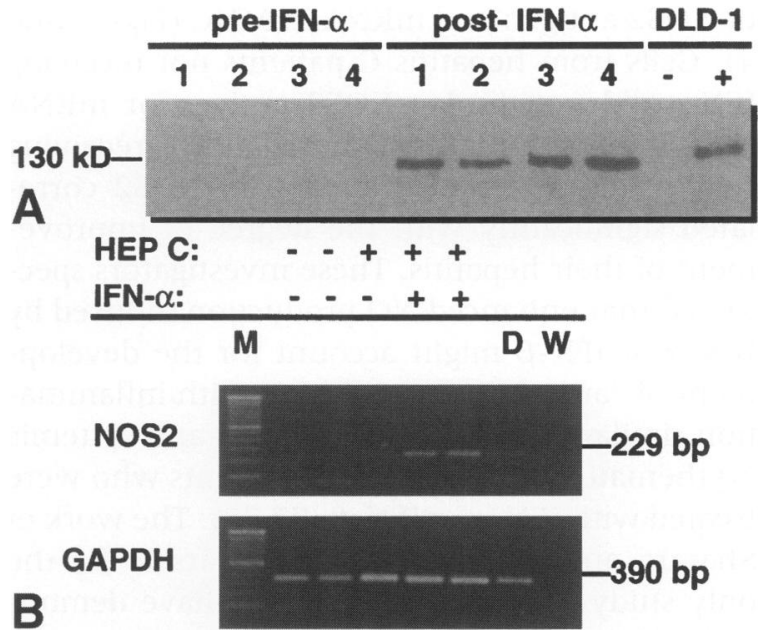

Fig. 4. Analyses of mononuclear cells from patients with and without hepatitis $C$ before and after IFN- $\boldsymbol{\alpha}$ treatment. (A) Immunoblot analyses of extracts of blood mononuclear cells from hepatitis $C$ patients before and after IFN- $\alpha$ treatment. Equivalent amounts of cellular protein were analyzed in each lane. Antibody 1E8-B8 was used. Samples from patients 1 to 4 were collected before IFN- $\alpha$ treatment (pre-IFN- $\alpha$ ) or after receiving IFN- $\alpha$ in vivo (post-IFN- $\alpha$ ). Controls for human NOS2 were from the human colon cancer cell line DLD- 1 without $(-)$ or with $(+)$ treatment with IFN- $\gamma$, IL- 1 , and TNF in vitro. (B) Reverse transcriptase-polymerase chain reaction analysis of mononuclear cells from normal subjects, patients with hepatitis $C$, and patients with hepatitis $C$ treated in vivo with IFN- $\alpha$. Cells were isolated, frozen, extracted, and analyzed as noted in Materials and Methods. Cells from the two normal subjects (HEP C - and IFN- $\alpha-$ ), one patient with hepatitis $C$ (HEP $C+$ and IFN- $\alpha-$ ), and two patients with hepatitis $C$ on treatment with IFN- $\alpha$ (HEP $\mathrm{C}+$ and IFN- $\alpha+$ ) were analyzed. M, molecular weight markers; D, cells of the human colon cancer cell line DLD- 1 treated with IFN- $\gamma$, IL- 1 , and TNF; W, distilled water. [Reproduced with permission (76).]

\section{Activation of Human Mononuclear Phagocytes for NO Production by Microbes}

Mycobacteria

Denis was the first to demonstrate that microbes could activate human monocytes for NO production (41). He noted that monocyte-derived macrophages (monocytes cultured for 7 days) from normal individuals treated in vitro with TNF and GM-CSF had enhanced ability to restrict the growth of virulent $M$. avium and to kill avirulent $M$. avium (41). The killing was inhibited by NMMA. While treatment of the cells with TNF 
and GM-CSF did not enhance nitrite formation, the treated cells produced nitrite when inoculated with $M$. avium (41). Dumarey et al. subsequently showed that infection of human monocytes with live, virulent $M$. avium induced nitrite formation (91). However, LPS, IFN- $\gamma$, and TNF had no effect on nitrite formation, and virulent strains of $M$. tuberculosis or avirulent $M$. avium also had no effect. Other investigators could not demonstrate induction of NO production by human monocytes or macrophages with inoculation of live or heat-killed M. avium complex (30). However, in this study, they did not co-incubate cytokines with the mononuclear phagocytes and mycobacteria. Bermudez found that the antimicrobial actions of human monocytes toward $M$. avium or Listeria monocytogenes were not inhibited by NMMA or arginase, and TNF, GM-CSF, and IFN- $\gamma$ did not cause nitrite production (48). Likewise, the microbes themselves did not enhance NO production.

\section{Protozoa and Helminths}

Sherman et al. noted that while LPS and IFN- $\gamma$ enhanced nitrite and L-citrulline production by mouse macrophages, they enhanced only L-citrulline formation by human alveolar macrophages (42). However, co-culture with Pneumocystis carinii caused a slight increase in both nitrite and L-citrulline formation by the human macrophages (42). Naotunne et al. noted that supernatants of human MNC cultured with extracts of freeze-thawed malarial parasites would inactivate gametocytes incubated with blood MNC (the gametocytes were subsequently unable to infect mosquitoes) (92). This suppressive effect was inhibited by NMMA. Seitzer et al. studied multinucleated giant cells that formed in vitro after culture of MNC with larvae of Nippostrongylus br brasiliensis. They demonstrated by RT-PCR analysis of single giant cells that 10 of 55 cells examined (18\%) contained NOS2 mRNA (93). NOS2 mRNA was present in 8 of $42(19 \%)$ foreign-body type giant cells and 2 of 13 (15\%) of Langhans giant cells. Macrophage giant cells also contained mRNA for IL-1, TNF, and IL-6. All examined cells were positive for NADPH-diaphorase; cells adherent to the nematodes stained most strongly.

\section{Viruses}

Some investigators have noted that HIV-1 or components of HIV-l activated human mono- cyte NO production. Pietraforte et al. found that HIV-1 envelope gp120 increased nitrite production by cultured monocytes (94). This production was inhibited by L-arginine analogues, and produced NO could also be demonstrated by use of the spin trap molecule DMPO. Bukrinsky and associates studied human monocytes after culture for 7 days with M-CSF and then subsequently infected with HIV-1 (61). Uninfected cells produced little or no NO, but those infected with HIV-1 produced significant amounts. Treatment of these cells with LPS or TNF, or coculture of the cells with astroglial cells further enhanced this NO formation. IL-4 or NMMA decreased the NO production. NO production was assessed by measurement of nitrite and detection by EPR of no "trapped" by Fe-DETC. Also, NOS2 mRNA was detected in infected and stimulated monocytes by RT-PCR (61). However, other investigators could not detect any significant increase in monocyte NO production after their infection with HIV-1 in vitro (30).

\section{Bacteria}

As noted above, Bermudez showed that L. monocytogenes did not enhance monocyte nitrite formation (48). Schneemann et al. found that human mononuclear phagocytes did not produce nitrite, consume L-arginine, produce L-citrulline or display NOS activity after culture with other agents and Listeria or Moraxella (51). Also, Weinberg and co-investigators tested other organisms for ability to activate monocytes for NO production [L. monocytogenes, Candida albicans, Staphylococcus epidermidis, M. avium complex, and $M$. tuberculosis (30)]. None of these enhanced NO production. On the other hand, Tufano et al. noted that porins extracted from Yersinia enterocolitica stimulated nitrite elaboration by normal monocytes in culture (95). There was a small amount of LPS contamination in the porins.

\section{Activation of Human Mononuclear Phagocytes for NO Production by Miscellaneous Agents}

A variety of other agents/materials have been tested for ability to stimulate normal human mononuclear phagocyte NO production. Belenky et al. did not measure NO production, but they did demonstrate that $\mathrm{L}$-arginine analogues attenuated the chemotactic peptide fMLP-induced chemotaxis and $\mathrm{FMLP}$-induced increases in CAMP in human 
monocytes, suggesting indirectly that NO production by these cells modulated their function (96). De Maria et al. found that treatment of monocytes with an antibody against the activation antigen CD69 antibody would trigger production of nitrite and nitrate (97). The antibody enhanced monocyte-mediated cytotoxicity for tumor cells, and this toxicity was inhibited by NMMA. The nitrite production was inhibited by NMMA. Perez-Mediavilla et al. found that oligopeptides from certain extracellular matrix proteins enhanced nitrite production and NOS2 protein expression by human monocytes (98). Production of nitrite was inhibited by NMMA. McLachlan and others noted that dehydroepiandrosterone (DHEA) stimulated nitrite formation by normal human monocytes (99). Nitrite production was higher in cells treated with both LPS and DHEA.

By using an NO-specific amperometric probe, Magazine and co-workers demonstrated that morphine enhanced monocyte NO formation (100). The NO production rate was rapid, with enhanced NO elaboration being detected within minutes of adding morphine to the cultures. Increased NO production was blocked by naloxone or by NMMA. NO production was also associated with cellular shape changes. Aymerich and colleagues showed that in vitro treatment of human monocytes with $\beta$-endorphin induced expression of NOS2 protein and enhanced nitrate production (101). The induction of NOS2 was noted if a mixture of monocytes and lymphocytes was treated in vitro, but it was not noted if purified monocytes were treated with $\beta$-endorphin. Stefano et al. found that normal human monocytes, when treated with the tetrahydrocannabinol derivative anandamide, produced NO (measured by a NO-specific amperimetric probe) (102). NO production occurred rapidly (within minutes of treatment), and Larginine analogues inhibited production. The cannabinoid antagonist SR 141716A (but not the morphine receptor antagonist naloxone) also blocked the NO-inducing effect.

King and co-workers noted that endothelin-1 induced rapid (within 2 to $4 \mathrm{~min}$ ) release of NO (measured by a NO-specific amperometric probe) from MNC and THP-l cells, and decreased adherence of MNC to endothelial cells (103). Endothelin-1 also caused rounding of THP-1 cells adherent to fibronectin-coated plates. This effect was prevented by an L-arginine analogue. Furthermore, NO release was blocked by BQ-788, an antagonist of $\mathrm{ET}_{\mathrm{B}}$ receptors. Lammas et al. found that monocyte-mediated killing of BCG organ- isms induced by treatment with ATP ("activation" mediated by $\mathrm{P} 2 \mathrm{Z}$ purinergic receptors) was not inhibited by L-arginine analogues (104). Vitek and co-workers demonstrated that cultured human monocytes pretreated with polyinosinic-polycytidylic acid had enhanced nitrite production if they were then cultured with apolipoprotein E (105). Amyloid beta peptide inhibited the apolipoprotein-induced increase.

\section{Human Conditions Associated with Mononuclear Phagocyte NOS2 Expression and NO Production}

The works discussed above have generally dealt with normal cells treated in vitro with various agents in attempts to stimulate NO production and NOS expression. In general, there is more convincing evidence that human mononuclear phagocytes can be "activated" in vivo by some means to express NOS and to produce NO. Some reports have documented NOS2 expression in monocytes and macrophages using immunohistology or immunocytology with specific antibodies, and in others, RT-PCR or in situ hybridization has shown NOS2 mRNA in mononuclear phagocytes in the tissues. Others have examined cells taken from blood or various tissues. Table 2 summarizes reports in which investigators examined mononuclear phagocytes from patients with various disease states for NO production and NOS2 expression.

\section{Hepatic Disease}

Hunt and Goldin noted that normal monocytes spontaneously generated nitrite with in vitro culture; the nitrite production was stimulated by LPS (32). Monocytes from alcoholic patients with or without liver disease had higher spontaneous nitrite production than did normal subjects (32). The nitrite production was inhibited by NMMA. In a comparable fashion, CriadoJiminez and co-workers found that MNC from alcoholic subjects produced nitrite, and that alcoholic subjects with cirrhosis produced even higher levels (106). The nitrite production was inhibited by L-arginine analogues. Likewise, Laffi et al. found that monocytes from patients with alcoholic cirrhosis with ascites spontaneously converted L-arginine to L-citrulline and inhibited thrombin-induced platelet aggregation (107). These activities were also inhibited by L-arginine analogues. Masini and co-workers noted that 
Table 2. Human conditions associated with mononuclear phagocyte NOS2 expression ${ }^{a}$

\begin{tabular}{|c|c|c|c|c|}
\hline Disorder & Reference & Cell & Assay & Comments \\
\hline \multicolumn{5}{|l|}{ Liver disease } \\
\hline Alcoholic hepatitis & $\begin{array}{l}\text { Hunt and Goldin, } \\
1992(32)\end{array}$ & Mo & Nitrite production in vitro & $\begin{array}{l}\text { None by those from normal } \\
\text { individuals; no treatment }\end{array}$ \\
\hline Alcoholic cirrhosis & $\begin{array}{l}\text { Criado-Jimenez et } \\
\text { al., } 1995 \text { (106) }\end{array}$ & MNC & Nitrite & Blocked by L-Arg analogue \\
\hline $\begin{array}{l}\text { Alcoholic cirrhosis with } \\
\text { ascites }\end{array}$ & $\begin{array}{l}\text { Laffi et al., } 1995 \\
\quad(107)\end{array}$ & Mo & $\begin{array}{l}\text { L-Arg to L-Cit, inhibition } \\
\text { of platelet aggregation }\end{array}$ & Inhibited by L-Arg analogues \\
\hline Cirrhosis & $\begin{array}{l}\text { Masini et al., } 1995 \\
\quad(108)\end{array}$ & Mo & $\begin{array}{l}\text { L-Arg to L-Cit, inhibition } \\
\text { of platelet aggregation }\end{array}$ & $\begin{array}{l}\text { Higher in Mo from patients } \\
\text { with cirrhosis; inhibited by } \\
\text { NMMA }\end{array}$ \\
\hline Hepatitis C patients & $\begin{array}{l}\text { Sharara et al., } 1997 \\
\quad(76)\end{array}$ & Mo, MNC & $\begin{array}{l}\text { Nitrite, nitrate, } \\
\text { immunoblot, L-Arg to } \\
\text { L-Cit, RT-PCR }\end{array}$ & $\begin{array}{l}\text { Induction of NOS2 activity } \\
\text { and Ag content by in vivo } \\
\text { treatment of hepatitis C } \\
\text { patients; correlation of } \\
\text { anti-viral activity of IFN- } \alpha \\
\text { with degree of NOS2 } \\
\text { induction }\end{array}$ \\
\hline Chronic viral hepatitis & $\begin{array}{l}\text { Majano et al., } 1998 \\
\quad(109)\end{array}$ & MNC & $\begin{array}{l}\text { Immunohistology, in situ } \\
\text { hybridization }\end{array}$ & $\begin{array}{l}\text { In chronic active hepatitis B } \\
\text { or C patients, NOS } 2 \text { protein } \\
\text { and mRNA noted in } \\
\text { hepatocytes, with only } \\
\text { mRNA noted in MNC in } \\
\text { hepatitis }\end{array}$ \\
\hline \multicolumn{5}{|l|}{ Lung disease } \\
\hline Lung inflammation & $\begin{array}{l}\text { Kobzik et al., } 1993 \\
\quad(111)\end{array}$ & Alv Mac & NOS2 immunohistology & \\
\hline Acute lung injury (ARDS) & $\begin{array}{l}\text { Haddad et al., } 1994 \\
\quad \text { (113) }\end{array}$ & Alv Mac & $\begin{array}{l}\text { Nitrotyrosine } \\
\text { immunohistology }\end{array}$ & $\begin{array}{l}\text { Presumed NO formation } \\
\text { leading to nitrotyrosine }\end{array}$ \\
\hline $\begin{array}{l}\text { Lung inflammation } \\
\text { (bronchiectasis and } \\
\text { bronchopneumonia) }\end{array}$ & $\begin{array}{l}\text { Tracey et al., } 1994 \\
\quad(112)\end{array}$ & Alv Mac & NOS2 immunohistology & $\begin{array}{l}\text { No staining in cells from } \\
\text { normal lung }\end{array}$ \\
\hline $\begin{array}{l}\text { Acute lung injury (ARDS, } \\
\text { sepsis, pneumonia) }\end{array}$ & $\begin{array}{l}\text { Kooy et al., } 1995 \\
\quad(114)\end{array}$ & Alv Mac & $\begin{array}{l}\text { Nitrotyrosine } \\
\text { immunohistology }\end{array}$ & $\begin{array}{l}\text { Presumed NO formation } \\
\text { leading to nitrotyrosine }\end{array}$ \\
\hline Pulmonary tuberculosis & $\begin{array}{l}\text { Kumar et al., } 1995 \\
\text { (117) }\end{array}$ & Mo & Nitrite & $\begin{array}{l}\text { Higher in cells from patients } \\
\text { tuberculosis pretreatment; } \\
\text { enhanced in vitro by LPS, } \\
\text { PPD, PMA, latex spheres }\end{array}$ \\
\hline Pulmonary tuberculosis & $\begin{array}{c}\text { Nicholson et al., } \\
1996 \text { (118) }\end{array}$ & Alv Mac & $\begin{array}{l}\text { Immunohistology, } \\
\text { immunoblot, RT-PCR }\end{array}$ & $\begin{array}{l}\text { Increased NOS2 in cells from } \\
\text { patients with tuberculosis }\end{array}$ \\
\hline Pulmonary tuberculosis & $\begin{array}{l}\text { Tunctan et al., } \\
1998 \text { (119) }\end{array}$ & Mo & $\begin{array}{l}\text { Nitrite; smooth muscle } \\
\text { relaxation }\end{array}$ & $\begin{array}{l}\text { Increased nitrite production } \\
\text { by LPS-treated cells from } \\
\text { normal subjects but not } \\
\text { those from tuberculosis } \\
\text { patients; supernatant media } \\
\text { from LPS-treated cells of } \\
\text { tuberculosis patients had } \\
\text { increased smooth muscle } \\
\text { relaxing activity }\end{array}$ \\
\hline Pulmonary tuberculosis & $\begin{array}{l}\text { Wang et al., } 1998 \\
\text { (120) }\end{array}$ & Alv Mac & $\begin{array}{l}\text { Flow cytometry, } \\
\text { immunohistology, } \\
\text { nitrite }\end{array}$ & $\begin{array}{l}\text { Higher NOS } 2 \text { expression and } \\
\text { nitrite production by cells } \\
\text { from tuberculosis patients; } \\
\text { nitrite production } \\
\text { correlated significantly with } \\
\text { exhaled NO concentration }\end{array}$ \\
\hline
\end{tabular}


Table 2. Human conditions associated with mononuclear phagocyte NOS2 expression ${ }^{a}$ (cont.)

\begin{tabular}{|c|c|c|c|c|}
\hline Disorder & Reference & Cell & Assay & Comments \\
\hline $\begin{array}{l}\text { Obliterative bronchiolitis } \\
\text { in lung transplant } \\
\text { patients }\end{array}$ & $\begin{array}{l}\text { McDermott et al., } \\
1997 \text { (115) }\end{array}$ & Alv Mac & $\begin{array}{l}\text { Immunohistology for } \\
\text { NOS2 and nitrotyrosine }\end{array}$ & $\begin{array}{l}\text { Co-localization of NOS } 2 \text { and } \\
\text { peroxynitrite with Mac }\end{array}$ \\
\hline Pulmonary fibrosis & $\begin{array}{l}\text { Nozaki et al., } 1997 \\
\quad(116)\end{array}$ & Alv Mac & $\begin{array}{l}\text { Immunocytology and } \\
\text { immunoblot for NOS2 } \\
\text { and nitrotyrosine, } \\
\text { RT-PCR }\end{array}$ & $\begin{array}{l}\text { Produced by alv Mac from } \\
\text { patients with pulmonary } \\
\text { fibrosis after in vitro } \\
\text { challenge with BCG; } \\
\text { NMMA inhibited Mac- } \\
\text { mediated BCG killing }\end{array}$ \\
\hline
\end{tabular}

\begin{tabular}{|c|c|c|c|c|}
\hline \multicolumn{5}{|l|}{ Cardiovascular disease } \\
\hline Atherosclerosis & $\begin{array}{l}\text { Beckman et al., } \\
1994(121)\end{array}$ & Vessel Mac & $\begin{array}{l}\text { Nitrotyrosine } \\
\text { immunohistology }\end{array}$ & $\begin{array}{l}\text { Presumed NO formation } \\
\text { leading to nitrotyrosine }\end{array}$ \\
\hline Myocardial infarct & $\begin{array}{l}\text { Wildhirt et al., } \\
1995(126)\end{array}$ & $\begin{array}{l}\text { Myocardial } \\
\text { Mac }\end{array}$ & Immunohistology & $\begin{array}{l}\text { NOS2 in infarcted } \\
\text { myocardium co-localized } \\
\text { with Mac }\end{array}$ \\
\hline Atherosclerosis & $\begin{array}{l}\text { Buttery et al., } 1996 \\
\quad(122)\end{array}$ & $\begin{array}{l}\text { Atherosclerotic } \\
\text { plaque } \\
\text { Mac }\end{array}$ & $\begin{array}{l}\text { Immunohistology, } \\
\text { immunoblot, in situ } \\
\text { hybridization, } \\
\text { nitrotyrosine }\end{array}$ & $\begin{array}{l}\text { Nitrotyrosine associated with } \\
\text { macrophages }\end{array}$ \\
\hline Giant cell arteritis & $\begin{array}{l}\text { Weyand et al., } \\
1996(127)\end{array}$ & Arterial Mac & Immunohistology & $\begin{array}{l}\text { NOS } 2 \text { in intimal Mac in giant } \\
\text { cell arteritis }\end{array}$ \\
\hline $\begin{array}{l}\text { Accelerated } \\
\text { arteriosclerosis in } \\
\text { transplanted hearts }\end{array}$ & $\begin{array}{l}\text { Lafond-Walker et } \\
\text { al., } 1997 \text { (125) }\end{array}$ & $\begin{array}{l}\text { Coronary } \\
\text { artery } \\
\text { Mac }\end{array}$ & $\begin{array}{l}\text { Immunohistology, in situ } \\
\text { hybridization }\end{array}$ & NOS2 associated with Mac \\
\hline Atherosclerosis & $\begin{array}{l}\text { Wilcox et al., } 1997 \\
\quad(123)\end{array}$ & Vessel Mac & $\begin{array}{l}\text { In situ hybridization, } \\
\text { immunohistology }\end{array}$ & $\begin{array}{l}\text { No NOS2 in normal vessels; } \\
\text { in atherosclerotic vessels, } \\
\text { Mac expressed NOS } 2 \text { and } \\
\text { NOS1 }\end{array}$ \\
\hline Atherosclerosis & $\begin{array}{l}\text { Luoma et al., } 1998 \\
\quad(124)\end{array}$ & Arterial Mac & Immunohistology & $\begin{array}{l}\text { NOS2 and nitrotyrosine } \\
\text { associated with Mac }\end{array}$ \\
\hline \multicolumn{5}{|l|}{ Allergic disease } \\
\hline Hay fever, asthma & $\begin{array}{l}\text { Mautino et al., } \\
1994(79)\end{array}$ & Mo & Nitrite & IL-4 treatment \\
\hline \multicolumn{5}{|l|}{ Arthritis } \\
\hline $\begin{array}{l}\text { RA and inflammatory } \\
\text { osteoarthritis }\end{array}$ & $\begin{array}{l}\text { Sakurai et al., } 1995 \\
\quad(128)\end{array}$ & $\begin{array}{l}\text { Synovial } \\
\text { Mac }\end{array}$ & $\begin{array}{l}\text { Nitrite, immunohistology, } \\
\text { immunoblot, RT-PCR }\end{array}$ & Inhibited by L-Arg analogue \\
\hline RA and osteoarthritis & $\begin{array}{l}\text { McInnes et al., } \\
1996 \text { (129) }\end{array}$ & $\begin{array}{l}\text { Synovial } \\
\text { Mac }\end{array}$ & $\begin{array}{l}\text { Nitrite, RT-PCR, } \\
\text { immunohistology }\end{array}$ & $\begin{array}{l}\text { NOS2 in synovial Mac and } \\
\text { synovial fibroblasts }\end{array}$ \\
\hline RA & $\begin{array}{l}\text { St. Clair et al., } \\
1996(67)\end{array}$ & Mo, MNC & $\begin{array}{l}\text { Nitrite, nitrate, } \\
\text { immunoblot, L-Arg to } \\
\text { L-Cit }\end{array}$ & $\begin{array}{l}\text { Increased L-Arg to L-Cit } \\
\text { activity and NOS } 2 \mathrm{Ag} \text { in } \\
\text { freshly isolated cells from } \\
\text { patients with RA; increased } \\
\text { responsiveness of MNC of } \\
\text { RA patients to IFN- } \gamma \text { in } \\
\text { vitro; inhibited by NMMA }\end{array}$ \\
\hline RA & $\begin{array}{l}\text { Grabowski et al., } \\
1997(130)\end{array}$ & $\begin{array}{l}\text { Synovial } \\
\text { Mac }\end{array}$ & Immunohistology & $\begin{array}{l}\text { NOS2 associated chiefly with } \\
\text { CD68+ Mac by } \\
\text { immunohistology; more } \\
\text { NOS2 in RA vs. } \\
\text { osteoarthritis; no NOS2 } \\
\text { noted in tissues from } \\
\text { normal subjects (hip } \\
\text { fractures) }\end{array}$ \\
\hline
\end{tabular}


Table 2. Human conditions associated with mononuclear phagocyte NOS2 expression ${ }^{a}$ (cont.)

\begin{tabular}{|c|c|c|c|c|}
\hline Disorder & Reference & Cell & Assay & Comments \\
\hline RA & $\begin{array}{l}\text { Perkins et al., } 1998 \\
\text { (131) }\end{array}$ & Mo, MNC & $\begin{array}{l}\text { Immunoblot, RT-PCR, } \\
\text { L-Arg to L-Cit }\end{array}$ & $\begin{array}{l}\text { Increased L-Arg to L-Cit } \\
\text { activity, NOS2 Ag, NOS2 } \\
\text { mRNA in MNC from } \\
\text { patients with RA; anti-TNF } \\
\text { antibody treatment in vivo } \\
\text { reduced the increased NOS } \\
\text { activity and NOS2 Ag } \\
\text { expression }\end{array}$ \\
\hline $\begin{array}{l}\text { Inflammatory response to } \\
\text { foreign body (joint } \\
\text { prostheses) }\end{array}$ & $\begin{array}{l}\text { Moilanen et al., } \\
1997 \text { (132) }\end{array}$ & $\begin{array}{l}\text { Foreign body } \\
\quad \text { Mac }\end{array}$ & Immunohistology, RT-PCR & NOS2 associated with Mac \\
\hline Loosened bone prosethesis & $\begin{array}{c}\text { Watkins et al., } \\
1997(133)\end{array}$ & $\begin{array}{l}\text { Mac around } \\
\text { loosened } \\
\text { bone hip } \\
\text { prostheses }\end{array}$ & $\begin{array}{l}\text { In situ hybridization, } \\
\text { immunohistology }\end{array}$ & No NOS2 in synovial cells \\
\hline
\end{tabular}

Cancer
Breast cancer
Various metastatic cancers
to pleural or peritoneal
spaces
Colon cancer

$\begin{array}{cc}\text { Thomsen et al., } & \text { Breast } \\ 1994(136) & \text { cancer } \\ & \text { Mac }\end{array}$

Wang et al., 1996

Ambs et al., 1998

(135)
Pleural or peritoneal Mac

Colon cancer MNC
Anti-NOS2 Ab

immunocytology, nitrite and nitrate, L-Arg to L-Cit

Nitrite

L-Arg to L-Cit, immunohistology for NOS2 and nitrotyrosine, immunoblot, RT-PCR
NOS2 associated with CD68+ Mac by immunohistol

More NO production by Mac from patients with cancer

NOS2 in tumors (more in adenomas than in carcinomas), but low in normal tissue; present in MNC, tumor cells, and endothelial cells; nitrotyrosine in MNC

Parasitic disease
$\begin{aligned} & \text { African children: normal } \\ & \text { and malarious }\end{aligned}$
$\begin{gathered}\text { Anstey et al., 1996 } \\ (138)\end{gathered}$

MNC NOS2 expression in normal Tanzanian children; increased NOS2 in asymptomatic and mild malaria; markedly decreased NOS2 in cerebral malaria

Renal disease
IgA nephropathy \&
proliferative glomerulo-
nephritis
IgA nephropathy, lupus
nephritis, membranous
nephropathy, and
minimal change
neprhotic syncrome

\section{Kashem et al., 1996 (66)}

Furusu et al., 1998 (139) Kidney Mac, Immunohistology, RT-PCR
Mo

Kidney Mac

Immunohistology, in situ hybridization
NOS2 associated with Mac

NOS2 primarily in mesangial cells and glomerular epithelial cells; inverse levels of expression of NOS3 and NOS2 in the kidneys with NOS2 correlating with degree of glomerular injury

\section{Bowel disease}

Crohn's disease, ulcerative colitis, diverticulitis
Immunohistology, RT-PCR
Found associated with Mac only at sites of inflammation 
Table 2. Human conditions associated with mononuclear phagocyte NOS2 expression ${ }^{a}$ (cont.)

\begin{tabular}{|c|c|c|c|c|}
\hline Disorder & Reference & Cell & Assay & Comments \\
\hline Ulcerative colitis & $\begin{array}{l}\text { Ikeda et al., } 1997 \\
\quad(141)\end{array}$ & Bowel Mac & Immunohistology & $\begin{array}{l}\text { Increased NOS2 in areas of } \\
\text { inflammation }\end{array}$ \\
\hline Celiac disease & $\begin{array}{l}\text { ter Steege et al., } \\
1997(143)\end{array}$ & Bowel Mac & Immunohistology & $\begin{array}{l}\text { Increased NOS } 2 \text { and } \\
\text { nitrotyrosine in Mac in } \\
\text { disease sites }\end{array}$ \\
\hline \multicolumn{5}{|l|}{ Multiple sclerosis } \\
\hline Multiple sclerosis & $\begin{array}{l}\text { Bo et al., } 1994 \\
\quad(144)\end{array}$ & Brain Mac & RT-PCR & $\begin{array}{l}\text { NOS2 NADPH diaphorase } \\
\text { activity detectable in brains } \\
\text { of MS patients }\end{array}$ \\
\hline Multiple sclerosis & $\begin{array}{l}\text { Bagasra et al., } 1995 \\
\text { (145) }\end{array}$ & Brain Mac & $\begin{array}{l}\text { Immunohistology, RT-in } \\
\text { situ-PCR }\end{array}$ & $\begin{array}{l}\text { NOS2 mRNA and } \\
\text { nitrotyrosine in Mac of } \\
\text { patients with multiple } \\
\text { sclerosis and absent in } \\
\text { "control" brains }\end{array}$ \\
\hline Multiple sclerosis & $\begin{array}{l}\text { De Groot et al., } \\
1997(146)\end{array}$ & Brain Mac & Immunohistology; nitrite & $\begin{array}{l}\text { In brains of patients with } \\
\text { multiple sclerosis, Mac } \\
\text { positive for both NOS2 and } \\
\text { "cNOS;" isolated Mac } \\
\text { produced NO }\end{array}$ \\
\hline Multiple sclerosis & $\begin{array}{l}\text { Hooper et al., } 1997 \\
\quad(147)\end{array}$ & Brain Mac & $\begin{array}{l}\text { Immunohistology, RT-in } \\
\text { situ-PCR }\end{array}$ & $\begin{array}{l}\text { NOS2 in brain Mac from } \\
\text { multiple sclerosis patients }\end{array}$ \\
\hline \multicolumn{5}{|l|}{ Pregnancy } \\
\hline Pregnancy & $\begin{array}{l}\text { Myatt et al., } 1997 \\
\quad(148)\end{array}$ & $\begin{array}{l}\text { Placental } \\
\text { Mac } \\
\text { (Hofbauer } \\
\text { cells) }\end{array}$ & Immunohistology, RT-PCR & NOS2 associated with Mac \\
\hline Pregnancy & $\begin{array}{l}\text { Eis et al., } 1997 \\
\quad(150)\end{array}$ & $\begin{array}{l}\text { Fetal } \\
\text { membrane } \\
\text { Mac }\end{array}$ & Immunohistology & $\begin{array}{l}\text { NOS2 associated with } \\
\text { membrane Mac; greater } \\
\text { NOS2 expression in } \\
\text { preterm labor vs. term } \\
\text { labor }\end{array}$ \\
\hline Pregnancy & $\begin{array}{c}\text { Zarlingo et al., } \\
1997 \text { (149) }\end{array}$ & $\begin{array}{l}\text { Placental } \\
\text { Mac }\end{array}$ & $\begin{array}{l}\text { Immunohistology, } \\
\text { immunoblot }\end{array}$ & \\
\hline \multicolumn{5}{|l|}{$\begin{array}{l}\text { Miscellaneous } \\
\text { conditions }\end{array}$} \\
\hline Trauma & $\begin{array}{l}\text { Kim et al., } 1995 \\
\text { (153) }\end{array}$ & Mo & Nitrite, nitrate & $\begin{array}{l}\text { Higher NO production in } \\
\text { PBMC from trauma } \\
\text { patients; some reduction of } \\
\text { NO production by IL-13 }\end{array}$ \\
\hline $\begin{array}{l}\text { Grave's disease } \\
\quad \text { (thyrotoxicosis) }\end{array}$ & $\begin{array}{l}\text { Lopez-Moratalla et } \\
\text { al., } 1996(152)\end{array}$ & Mo & Immunocytology & $\begin{array}{l}\text { NOS2 in freshly isolated Mo } \\
\text { from Grave's; increased } \\
\text { activity induced by in vitro } \\
\text { treatment with peptides } \\
\text { from thyroid autoantigens }\end{array}$ \\
\hline Sickle cell disease & $\begin{array}{r}\text { Dias-Da-Motta et } \\
\text { al., } 1996(154)\end{array}$ & PBMC & $\begin{array}{l}\text { Inhibition of platelet } \\
\text { aggregation }\end{array}$ & $\begin{array}{l}\text { Inhibited by L-Arg analogue; } \\
\text { production noted only in } \\
\text { presence of SOD; more } \\
\text { activity in cells from } \\
\text { patients with sickle cell } \\
\text { disease }\end{array}$ \\
\hline
\end{tabular}

\footnotetext{
${ }^{a}$ For abbreviations, see Table 1.
} 
monocytes from individuals with cirrhosis produced more NO than did those from normal individuals (108).

Sharara and associates studied MNC from individuals with hepatitis $C$ who were or were not being treated with IFN- $\alpha$ (76). Cells from hepatitis $C$ patients not receiving IFN- $\alpha$ did not display NOS 2 antigen or MRNA, and their NOS enzyme activities were comparable to those of normal individuals. In patients with hepatitis $\mathrm{C}$, administration of IFN- $\alpha$ in vivo increased NOS enzyme activity and caused the appearance of NOS2 antigen and mRNA in MNC (Figs. 3 and 4). In those patients receiving IFN- $\alpha$, the degree of induction of NOS2 correlated significantly with the degree of improvement of their hepatitis. Treatment of mononuclear cells in vitro enhanced NO production, NOS activity, and NOS2 protein and mRNA expression, and this was accompanied by general improvement in the hepatitis (75) (Fig. 2). In a different study, Majano and associates, using immunohistology and in situ hybridization, studied liver biopsy material from patients with chronic active hepatitis B or C, alcoholic hepatitis, and cholestasis (109). Large amounts of NOS2 protein and mRNA were noted in hepatocytes in patients with hepatitis B or C with small amounts of NOS2 mRNA (but not protein) in mononuclear cells in the liver. These patients were apparently not receiving IFN- $\alpha$ Liver tissue from patients without liver disease, and from patients with nonviral liver disease expressed no or very little NOS2 (109). Majano et al. studied liver biopsy material from patients with viral and nonviral liver diseases using immunohistology and in situ hybridization techniques (110). They noted NOS2 mRNA and protein in hepatocytes from patients with viral hepatitis, but little or none was noted in hematopoietic cells in the livers.

\section{Pulmonary Disease}

In a histologic and cytologic study, Kobzik et al. found that human alveolar macrophages contained NADPH diaphorase activity and NOS2 antigen (111). Antigen content was greater in areas of inflammation. Tracey and others noted using immunohistology that NOS2 was expressed in alveolar macrophages from patients with bronchiectasis and patients with pneumonia (112). In contrast, no cells in normal lung contained the antigen. Haddad et al., using immunohistology and immunocytochemistry, showed that human alveolar macrophages from patients with acute lung injury (adult respiratory distress syndrome [ARDS]) contained nitrotyrosine (113). Although tissue from patients without lung injury contained small amounts of nitrotyrosine, there was two times more in those from patients with acute lung injury. The presence of nitrotyrosine was presumptive evidence that NO had been formed and had reacted with superoxide to form peroxynitrite; peroxynitrite then caused nitration of tyrosine (23).

In studies using tissues from autopsies of patients with acute lung injury, Kooy et al. noted the presence of nitrotyrosine in alveolar macrophages, alveolar epithelium, lung interstitium, and proteinaceous alveolar exudate (114). In patients with sepsis-induced diffuse alveolar damage, there was extensive staining of the endothelium and subendothelial tissues. McDermott and associates showed by immunohistology that lung transplant patients with obliterative bronchiolitis had alveolar macrophages that contained NOS2 and nitrotyrosine (115); NOS2 and nitrotyrosine were also seen in neutrophils, airway epithelium, and vascular endothelium. Little or no reactivity was observed in control lungs. Nozaki et al. noted that alveolar macrophages from patients with idiopathic pulmonary fibrosis contained NOS2 antigen and nitrotyrosine, as well as NOS2 mRNA after they were inoculated in vitro with BCG (116). Alveolar macrophages from these patients were able to kill BCG organisms, and this killing was inhibited by NMMA. Alveolar macrophages from patients with lung cancer or nonmalignant pulmonary nodules did not express NOS2 and did not kill BCG.

In studies of monocytes from patients with pulmonary tuberculosis, Kumar and associated found that monocytes stimulated in vitro with LPS, PPD, PMA, or latex spheres produced nitrite and L-citrulline (117). Nitrite and L-citrulline production were higher in subjects before their tuberculosis had been treated. Nicholson et al. found that alveolar macrophages from patients with tuberculosis expressed NOS2 antigen (immunocytology and immunoblot using a highly specific antibody for human NOS2) and mRNA (RT-PCR) (118). Sixty-five percent of alveolar macrophages from $11 / 11$ patients with untreated tuberculosis expressed NOS2, but only $10 \%$ of alveolar macrophages from five normal subjects expressed the antigen. Alveolar macrophages from patients with other inflammatory disorders such as pneumonia, cancer, and sarcoidosis also contained NOS2. Tunctan and co-workers noted that blood monocytes from normal subjects produced increased lev- 
els of nitrite after treatment with LPS in vitro (nitrate levels were not measured). Monocytes from patients with pulmonary tuberculosis did not produce increased levels of nitrite after LPS treatment (119). They concluded that monocyte NO production was reduced in tuberculosis patients. However, using a bioassay for NO (methylene blueinhibitable relaxation of constricted guinea pig aorta smooth muscle by supernatant medium from cultures), the researchers noted that fluids from LPS-treated cultures of monocytes from controls or tuberculosis patients caused more relaxation (119).

In a different study, Wang and co-workers studied alveolar macrophages from normal individuals and from patients with pulmonary tuberculosis before and after treatment (120). Using an anti-NOS2 antibody and flow cytometry and immunohistology, they noted that alveolar macrophages from patients with active tuberculosis had more NOS2 antigen expressed than those of control subjects. Likewise, cells from tuberculosis patients could produce more nitrite, and there was more NO in their exhaled air (120). Levels of NO in exhaled air correlated significantly with the capacity of alveolar macrophages to produce nitrite in vitro.

\section{Cardiovascular Disease}

In immunohistology and immunoblot studies of human arterial atheromata, Beckman et al. found extensive nitration of protein tyrosines associated with macrophages (121). Buttery et al. showed that human atherosclerotic lesions contained NOS2 and nitrotyrosine in association with macrophages, foam cells, and smooth cells (122). They also used in situ hybridization for NOS2 to demonstrate evidence of NOS2 mRNA, and immunoblot analysis to confirm that the NOS2 protein isoform was present. The presence of nitrotyrosine indicated that peroxynitrite formed in the lesions; they suggested that NO, peroxynitrite, or other NO-derived molecules might be important mediators of the pathology of these lesions. Wilcox et al. used in situ hybridization and immunohistology to show that in normal human vessels there is no expression of NOS2 or NOS1, but that endothelial cells express NOS3 (123). In atherosclerotic vessels, there was decreased in NOS 3 over the lesions and increased expression of NOS1 and NOS2 in a variety of cells, including macrophages. Luoma and colleagues demonstrated macrophages in atherosclerotic lesions that expressed NOS2 and contained nitrotyrosine (124). In these same lesions, there were high levels of expression of extracellular superoxide dismutase (SOD).

Lafond-Walker et al., using immunohistology and in situ hybridization, noted NOS2 antigen and mRNA in macrophages in transplanted hearts undergoing accelerated graft arteriosclerosis (125). NOS2 was noted in the neointima in 7 of 10 of the transplanted vessels with accelerated graft arteriosclerosis, but was absent from 5 arteries with atherosclerosis and from 2 normal coronary arteries. They noted no relationship between NOS2 expression and levels of the immunosuppressive drug cyclosporine $\mathrm{A}$.

Wildhirt and associates found NOS2 associated with macrophages in areas of myocardial infarction in humans 7 and 25 days after infarct (126). Weyand et al., using immunohistologic studies, found NOS2 in intimal macrophages in arteries from patients with giant cell arteritis (127). Significantly, CD68+ macrophages that expressed TGF- $\beta$ were positive for IL- 6 and IL- 1 but negative for NOS2; they were localized in the adventitia. CD68+ macrophages that expressed NOS2 were negative for TGF- $\beta$ and positive for $72 \mathrm{kD}$ collagenase. Nonmacrophage cells (probably smooth muscle cells) in the inflammatory lesions also expressed NOS2 (127).

\section{Allergic Disease}

As noted above in the discussion about IgE, $\mathrm{CD} 23$, and NO, several investigators have demonstrated the importance of IgE and CD23 relative to monocyte NO formation. Mautino et al. noted that IL-4 would enhance nitrite production by monocytes to varying degrees by cells from different donors (80). When Mautino et al. divided his subjects into "low-producers" and "high-producers" of NO after treatment with IL-4 in vitro, differences appeared with regard to the allergy status of the individuals. IL-4 augmented nitrite production by cells from "low producers," whereas it decreased production by cells from "high producers." Allergic subjects (those with hay fever or asthma) appeared to have increased production of NO (80).

\section{Rheumatologic Disease}

There are numerous reports regarding the proinflammatory effects of $\mathrm{NO}$ in animal models of arthritis (see ref. 3 for review). There is also excellent information showing that in mononuclear phagocytes there is enhanced expression of NOS2 and increased production of NO in inflam- 
matory arthritis in humans. In a study of human synovial cells from patients with inflammatory arthritides, Sakurai et al. showed that synovial macrophages produced nitrite, contained NOS2 antigen (immunohistology and immunoblot), and expressed NOS2 mRNA (128). NO production was inhibited by L-arginine analogues. The NOS2 expression and nitrite production were noted in both RA and inflammatory osteoarthritis. McInnes et al. studied synovial membrane cells from patients with osteoarthritis and RA (129). They found increased nitrite production in cultures of these tissues, and noted that synovial macrophages expressed NOS2. However, the most abundant cells expressing NOS2 were synovial fibroblasts. Other researchers noted in immunohistology studies of resected joint specimens that RA patients had large numbers of $\mathrm{CD} 68+$ macrophages in the synovial lining areas that contained NOS2 (130). Chondrocytes, fibroblasts, and smooth muscle cells also contained small amount of NOS2. Tissues from osteoarthritis patients had less NOS2 expression, and tissue from patients without arthritis (hip fracture) had no NOS2 expression (130).

St. Clair and associates found that freshly isolated monocytes and MNC from patients with active RA (when compared with those of normal subjects) had increased NOS enzyme activity and increased NOS2 antigen expression (immunoblot) (67) (Fig. 5). When MNC were cultured with IFN- $\gamma$, they had increased production of nitrite/nitrate whereas those of normal subjects were not altered. NMMA inhibited the NOS activity. Levels of NOS2 enzyme activity and NOS2 antigen were positively correlated with the severity of arthritis. Investigators of this group also studied RA patients receiving treatment with the chimeric, monoclonal anti-tumor necrosis factor- $\alpha$ antibody cA2 (131). This antibody has been found to induce dramatic improvement in arthritis in the majority of RA patients treated. Perkins and associates confirmed the increased blood MNC expression of NOS enzyme and NOS2 antigen in RA. They found that cells from patients who had received anti-TNF antibody treatment 4 weeks earlier had a decrease in the overexpression of MNC NOS2 antigen (Fig. 6) and NOS activity. Antibody-induced changes in NOS activity and NOS2 antigen expression correlated significantly with changes in the number of tender joints (greater improvement in arthritis induced by the antibody correlated with greater reduction in NOS) (Fig. 7). They speculated that antibody-induced decreases in NOS overexpres- sion might account (wholly or in part) for the treatment-related clinical improvement in arthritis (131). This study is unique in that the work documents that the degree of pharmacologic inhibition of NOS2 expression in human blood mononuclear cells correlates significantly with the agent-induced clinical improvement.

Moilanen et al. demonstrated by immunohistology that foreign body macrophages in the granulomatous, pseudosynovial membrane adjacent to loosened joint prostheses contained NOS2 in 10 of 13 cases examined (132). CD23 was not detectable. Calcium-independent NOS enzyme activity was detected in 12 of 13 specimens studied. RT-PCR analysis revealed NOS2 mRNA in 3 of 3 tissue samples studied, while normal blood monocytes were negative. In a comparable study, Watkins et al. demonstrated by immunohistology and in situ histochemistry that human macrophages in the interfacial membrane and pseudocapsule surrounding failed prosthetic hip joints contained NOS2 (133). Several of the NOS2-positive macrophages had phagocytized polyethylene debris from the prosthesis.

\section{Neoplastic Disease}

Thomsen et al. noted that macrophages within human breast cancer specimens produced nitrite and nitrate and contained NOS2 (134). There was a general positive relationship between the grade of malignancy and the amount of NOS content. Ambs and co-workers examined resected specimens from individuals with colon adenomas and adenocarcinomas for NOS activity and NOS2 expression (135). They found calcium-dependent NOS enzyme activity in normal colon tissue, but levels were lower in adenomas and carcinoma tissues (possibly indicative of a general decrease in endothelial cells and autonomic neurons in colon tumors). However, levels of calcium-independent NOS (NOS2) were much higher in adenomas and carcinomas, with very low levels in normal tissues adjacent to the tumors. Calcium-independent NOS activity in tumors decreased with increasing stage of the tumor, with the lowest activities being noted in metastatic tumors. Immunoblot and RT-PCR analyses detected NOS2 protein and mRNA in the tumor tissue. Normal colon epithelium, colon cancer cells, and MNC expressed NOS2 antigen, while only MNC (and rare PMN) expressed nitrotyrosine (135).

In a study of gynecological tumors (ovarian, endometrial, and mixed mesodermal), Thomsen 


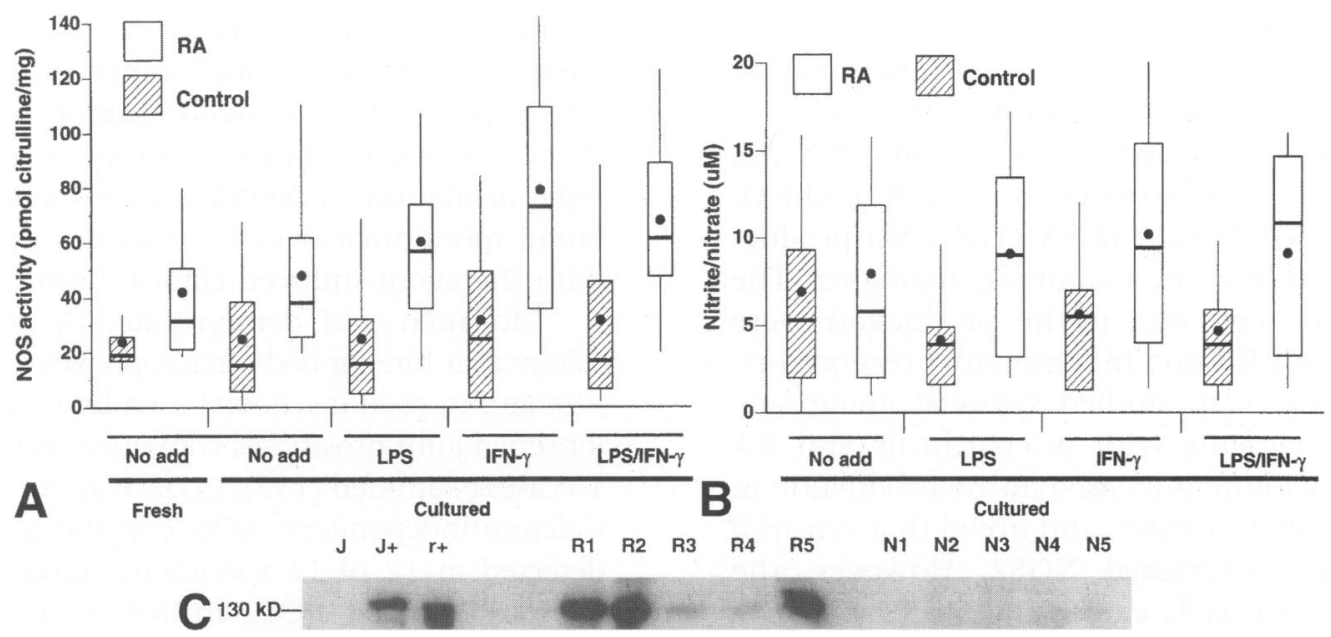

Fig. 5. NOS activity, nitrite/nitrate, and NOS2 antigen in mononuclear cells from control subjects and RA patients. (A) NOS activity in freshly isolated and cultured mononuclear cells from control subjects and RA patients. Blood mononuclear cells were prepared and extracts from freshly isolated cells ("fresh") or from cells cultured 5 days with no additions, with $1 \mu \mathrm{g} / \mathrm{ml}$ LPS alone, with $500 \mathrm{U} / \mathrm{ml}$ IFN- $\gamma$ alone, or with $500 \mathrm{U} / \mathrm{ml}$ IFN- $\gamma$ and $1 \mu \mathrm{g} / \mathrm{ml}$ LPS were assayed for NOS activity (ability to convert $\mathrm{L}$-arginine to L-citrulline). Assays were done as six replicates for each individual subject. Results are shown as medians (horizontal bar), means (circle), the interquartile range (box), and the 10th to 90th percentile range (vertical lines). There were 20 control subjects and $25 \mathrm{RA}$ patients. Using the Wilcoxon Rank Sum test, RA patients' NOS activities differed significantly from control subjects' NOS activities in the categories Fresh $(p<0.003)$, No additions $(p<$ $0.005)$, LPS $(p<0.002)$, IFN- $\gamma(p<0.002)$, and LPS/IFN- $\gamma(p<0.002)$. In analyses of cultured cells, the within-group comparison was significant for RA patients $(p<0.001)$, but not for control subjects. Pairwise comparisons for cells from RA patients revealed significant differences for treatments which included IFN- $\gamma$ [No additions vs. IFN- $\gamma(p<0.003)$, and No additions vs. LPS/IFN- $\gamma(p<0.003)]$. (B) Nitrite/nitrate production by cultured mononuclear cells from normal subjects and RA patients. Blood mononuclear cells were prepared and cultured 5 days with no additions, $1 \mu \mathrm{g} / \mathrm{ml}$ LPS alone, 500 $\mathrm{U} / \mathrm{ml}$ IFN- $\gamma$ alone, or $500 \mathrm{U} / \mathrm{ml} \mathrm{IFN-} \gamma$ and $1 \mu \mathrm{g} / \mathrm{ml}$

and associates noted high levels of NOS enzyme activity in tumor cells, but not in normal gynecological tissues (136). Immunohistology showed that NOS2 antigen was in tumor cells, but notin normal tissue. Other workers showed that central nervous tumors (astrocytoma, meningioma, Schwannoma, ependymoma, medulloblastoma, and mixed glioma) had NOS activity and expressed NOS1 and NOS2. In general, the highest levels of expression were in the tumors with the highest
LPS. Supernatant media were then measured for nitrite/nitrate. Assays were done as six replicates for each individual subject. Results are shown as medians (horizontal bar), means (circle), the interquartile range (box), and the 10th to 90th percentile range (vertical lines). There were 20 control subjects and 25 RA patients. Using the Wilcoxon Rank Sum test, RA patients' nitrite/nitrate levels differed significantly from control subjects' nitrite/nitrate levels in the categories LPS $(p<0.01)$ and LPS + IFN- $\gamma(p<$ 0.02 ). Within-group comparison was significant for control subjects $(p<0.02)$, but not for RA patients. Pairwise comparisons for cells from control subjects revealed significant differences for No additions vs. LPS $(p<0.02)$ and "LPS" vs. IFN- $\gamma(p<0.003)$. (C) Immunoblot analysis of mononuclear cells from normal controls and RA patients for NOS2 expression. Blood mononuclear cells were isolated and extracts were analyzed for NOS2 antigen content using an NOS2-specific mouse monoclonal anti-NOS2 antibody. The NOS2 antigen has a molecular weight of approximately $130 \mathrm{kD}$. Extracts from the murine macrophage cell line cells J774 and RAW 264 were used as negative and positive controls. Forty micrograms of protein from the extracts were used in each lane. Parallel gels and blots done using isotype-specific control immunoglobulin showed no reactivity. $\mathrm{J}=\mathrm{J} 774$ control; $\mathrm{J}+=\mathrm{J} 774$ cells cultured with LPS + IFN- $\gamma ; \mathrm{r}+=$ RAW 264 cells cultured with LPS + IFN- $\gamma ; \mathrm{Rl}-5=$ samples from 5 separate RA patients; $\mathrm{Nl}-5=$ samples from 5 separate normal (control) subjects. [Reproduced with permission (67).]

histologic tumor grades (137). Hematopoietic cells in the tumor tissue were not reported to express NOS or NADPH diaphorase activity.

\section{Parasitic Disease}

Anstey et al. studied Tanzanian children on a diet low in nitrite/nitrate to determine the influence of malaria on MNC NOS2 expression and NO production, and to determine if these parameters 


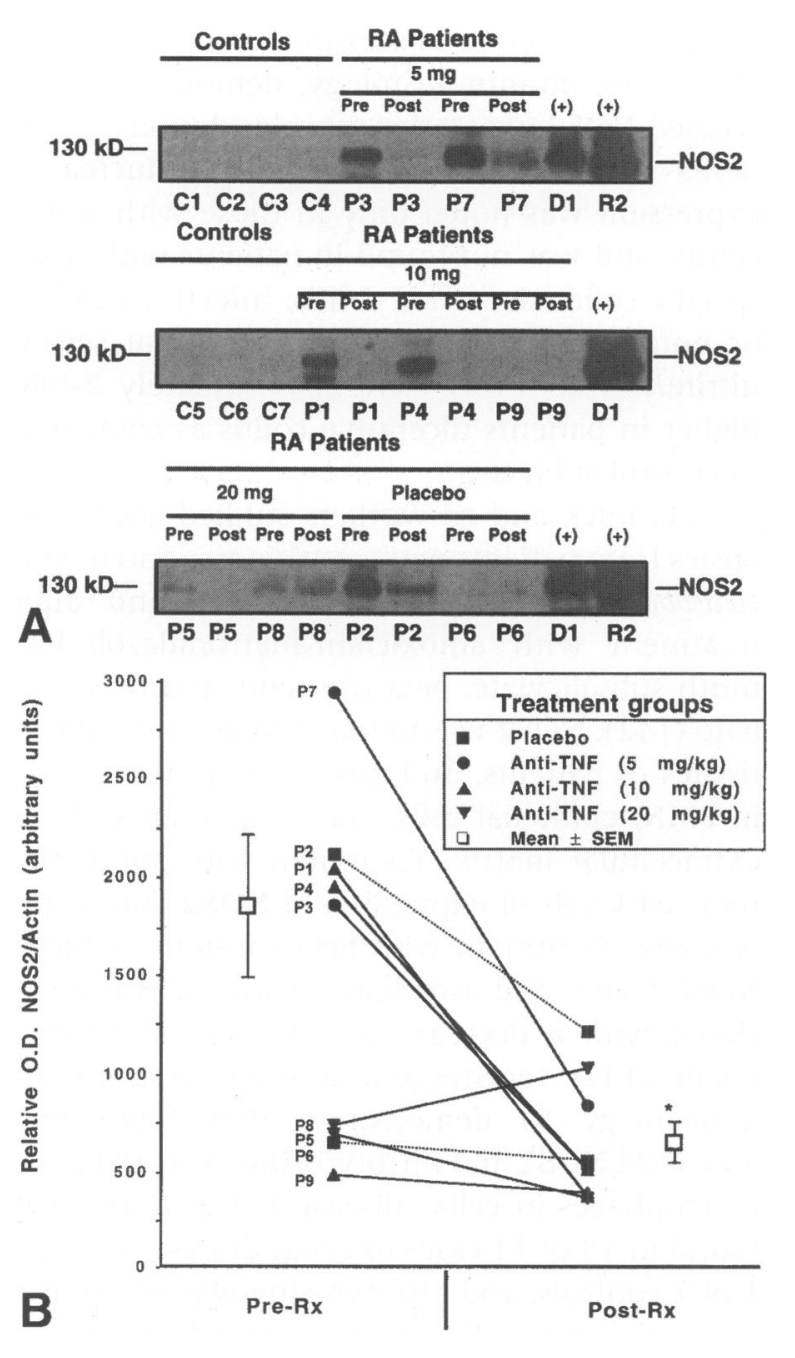

Fig. 6. Evaluation of NOS2 antigen expression at baseline and 4 weeks post-treatment with anti-TNF- $\alpha$ antibody (cA2). (A) Immunoblot analysis of NOS2 antigen expression in blood mononuclear cells isolated from healthy control subjects (C1-C7), patients with RA (P1-P9) at baseline measurements (Pre) and 4 weeks after a single infusion of $5 \mathrm{mg} / \mathrm{kg}, 10 \mathrm{mg} / \mathrm{kg}$, or $20 \mathrm{mg} / \mathrm{kg}$ of $\mathrm{cA} 2$, or a placebo (Post). Positive controls for NOS2 antigen expression included stimulated human adenocarcinoma cells (DLD-1, designated D1), and stimulated mouse macrophage cells (RAW 264.7, designated R2). All immunoblotting was performed concomitantly with exactly the same exposure time so that comparisons between subjects were valid. (B) Relative optical density expressed as NOS2/actin in arbitrary units. Solid lines represent RA patients infused with of $5 \mathrm{mg} / \mathrm{kg}(1), 10 \mathrm{mg} / \mathrm{kg}(\mathrm{s})$, or $20 \mathrm{mg} / \mathrm{kg}(\mathrm{t})$ of cA2, whereas dashed lines represent RA patients infused with a placebo(n). The open squares represent the means \pm SEM of the pre- and post-treatment values. The asterisk denotes statistical significance of $p<0.03$ for differences between the levels of NOS2/ actin before and 4 weeks after treatment with cA2 ( $n=7$; P1, P3, P4, P5, P7, P8, and P9). [Reproduced with permission (131).]

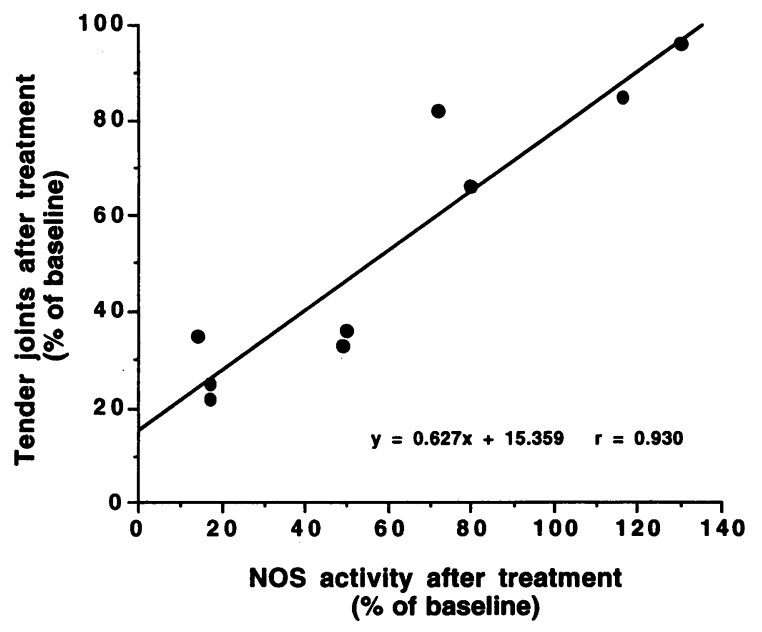

Fig. 7. Correlation between blood mononuclear cell NOS enzyme activity and tender joint count after treatment with anti-TNF- $\alpha$ antibody (cA2). Blood mononuclear cells from RA patients were assayed before and 4 weeks after a single infusion of $5 \mathrm{mg} / \mathrm{kg}, 10 \mathrm{mg} / \mathrm{kg}$, or $20 \mathrm{mg} / \mathrm{kg}$ of cA2, or a placebo. NOS activity $\left({ }^{14} \mathrm{C}\right.$-L-arginine conversion to ${ }^{14} \mathrm{C}$-L-citrulline) was expressed as the percent of baseline value and compared with the number of tender joints also expressed as the percent of baseline value. All patients (P1-P9) were included in this analysis. [Reproduced with permission (131).]

related to disease severity (138). They found that urine and plasma levels of nitrite/nitrate (corrected for renal function impairment) correlated inversely with disease severity, with highest levels in subclinical infection and lowest in fatal cerebral malaria. Likewise, blood MNC NOS2 antigen was detectable by immunoblot in all control children and in all those with subclinical infection, but it was undetectable in all but one subject with cerebral malaria. Quantitated MNC NOS2 antigen levels paralleled plasma nitrite/ nitrate levels, and they were inversely related to disease severity. Levels of IL-10, a cytokine known to suppress NO synthesis, increased with disease severity (138). The authors hypothesized that high levels of IL-10 in severe disease might decrease NOS expression and NO production. On the basis of their data, they also suggested that NO had a protective (rather than a pathological) role in African children with malaria. It is important to note that the healthy control African children of this study had constitutive expression of MNC NOS2 and relatively high levels of plasma and urine nitrite/nitrate (138). Studies in U.S. adults have only rarely found NOS2 antigen expression in MNC or monocytes from normal individuals $(30,67,76)$. Anstey et al. have postu- 
lated that the constitutive expression of NOS2 may be related to subclinical malaria or other infection, or to genetic differences in the control of NOS2 expression.

\section{Renal Disease}

Kashem et al. demonstrated by immunohistology that renal macrophages from patients with IgA nephropathy or proliferative nephropathy contained NOS2 antigen (66). They also found that kidney biopsy samples from these patients contained NOS2 mRNA, as determined by RTPCR. Normal kidney samples expressed neither NOS2 antigen nor mRNA. Furusu and co-workers studied kidney biopsy material from humans with IgA nephropathy, lupus nephritis, membranous nephropathy, minimal change nephrotic syndrome, and control individuals (those in whom no pathology was noted on biopsy) (139). Using immunohistology and in situ hybridization techniques, they noted expression of NOS3 in glomerular endothelial cells and cortical vessel endothelium in both diseased and normal kidneys. There was no or little expression of NOS2 protein in kidneys from controls and patients with membranous nephropathy and minimal change nephrotic syndrome, but NOS2 was expressed strongly in mesangial cells and glomerular epithelial cells in kidneys from patients with IgA nephropathy and lupus nephritis. From studies with the anti-macrophage antibody antiCD68, they concluded that while some macrophages expressed NOS2, the majority of NOS2containing cells were intrinsic glomerular cells (mesangial cells and clomerular epithelial cells). There were inverse levels of expression of NOS3 and NOS2 in the kidneys, and in IgA nephropathy and lupus nephritis, the extent of staining for NOS 3 correlated negatively with the degree of glomerular pathology while that of NOS2 correlated positively with the degree of injury (139).

\section{Gastrointestinal Disease}

Singer et al., using immunohistology and RTPCR, demonstrated NOS2 antigen and mRNA in samples of colonic epithelium from patients with inflammatory bowel disease (140). The NOS2 was in association with macrophages in areas of inflammation in patients with ulcerative colitis, Crohn's disease, and diverticulitis. Areas of inflammation also contained nitrotyrosine, indicating that peroxynitrite had also been formed. NOS2 was also noted in neutrophils in the colon lumen and in crypt abscesses. Ikeda and associates, using immunohistology, demonstrated increased NOS2 expression in colon lesions in patients with ulcerative colitis (141). Increased expression was noted only in those with active colitis, and was not found in patients with nonspecific colitis, ischemic colitis, infectious colitis, or normal colons. They also noted that serum nitrite/nitrate levels were approximately 2 -fold higher in patients ulcerative colitis as compared to control subjects.

Mannick and co-workers studied gastric biopsies from patients with gastritis associated with Helicobacter pylori infection, before and after treatment with amoxicillin-metronidazole-bismuth subsalicylate, beta carotene, and/or ascorbate (142). NOS2 was noted in MNC and PMN in tissues of patients, and nitrotyrosine was found in PMN, epithelial cells, and components of the extracellular matrix. Treatment with antibiotics reduced levels of expression of NOS2 and nitrotyrosine. Treatment with beta carotene reduced NOS2 levels, and ascorbate treatment was associated with a decrease in staining for nitrotyrosine (142). ter Steege and others used immunohistology to demonstrate that there was increased NOS2 and nitrotyrosine in small bowel macrophages in celiac disease (143). NOS2 was found in 10 of 11 cases of celiac disease but only 1 of 7 controls, and nitrotyrosine was noted in 5 of 6 cases and 0 of 6 controls examined. Nitrityrosine was noted in association with the NOS2 positive cells.

\section{Multiple Sclerosis}

Using RT-PCR analysis, Bo et al. demonstrated that brains of patients with multiple sclerosis (MS) contained macrophages in the demyelinating regions that expressed mRNA for NOS2 (144). There was NADPH diaphorase activity in these regions. Bagasra and co-workers found NOS2 mRNA (using RT-in situ-PCR) and nitrotyrosine in the brains of 7/7 MS patients, while none was found in brains of three individuals without MS (145). DeGroot et al. showed both NOS2 and "cNOS" in macrophages in brains of MS patients (146). They also noted that isolated brain macrophages produced nitrite in vitro. In comparable studies, Hooper and colleagues showed NOS2 mRNA and protein in macrophages in brains of patients with MS (147). 


\section{Pregnancy}

Myatt et al. examined placentas from normotensive, pre-eclamptic, and intrauterine growth-restricted pregnancies (148). They showed that NOS2 was present and localized with $\mathrm{CD} 14+$ macrophages (also termed Hofbauer cells), but there was no difference among the three groups of patients with regards to NOS2 staining. NOS2 was also seen in syncytiotrophoblast and vascular endothelium in some cases. RT-PCR analysis of placental samples showed the presence of NOS2 mRNA. Zarlingo and co-workers showed NOS2 staining in placental villous stomal macrophages of humans and other species (149). They noted NOS2 in placental syncytiotrophoblasts and in vascular endothelial cells. In studies of human fetal membranes, Eis et al. demonstrated NOS2 in decidual macrophages and other cell types (150). The intensity of NOS2 staining was greater in membranes of those with preterm labor as compared to those with no labor. There was no NOS2 staining in amnion epithelium or chorion trophoblast.

\section{Miscellaneous Conditions}

Condino-Neto et al. noted that MNC from patients with chronic granulomatous diseases (cells lacking a component of NADPH oxidase and thus incapable of producing superoxide) inhibited thrombin-induced platelet aggregation and that this inhibition was blocked by an L-arginine analogue (151). However, they did measure any NO parameters. López-Moratalla et al. noted that Grave's disease patients spontaneously expressed NOS2 antigen in freshly isolated monocytes (152). Monocyte NOS2 antigen content was further increased by treatment of the cells in vitro with peptides from certain thyroid autoantigens (thyrotropin receptor, thyroid peroxidase, and thyroglobulin). Kim et al. noted that monocytes from patients with trauma produced more NO after in vitro LPS treatment than did those of normal individuals (153). This NO production was decreased by treatment with IL-3 in vitro. DiasDa-Motta et al. showed that PBMC from patients with sickle cell anemia produced NO that detectable in assays of platelet aggregation inhibition only in the presence of SOD (154). However, this activity was not different than that noted in comparable cells from normal individuals.

\section{Conclusions}

The literature regarding NOS2 expression and NO production by mononuclear phagocytes from humans and other species documents the ability of human monocytes and tissue macrophages to express NOS2 mRNA and protein, and to produce NO. It is difficult to quantitatively compare levels of NO production and NOS2 expression by human and murine mononuclear phagocytes. However, based on several studies in which both murine and human cells were examined in parallel using the same conditions in vitro, human cells probably produce less NO and express lower levels of NOS2 than do murine cells. It is important to note that studies have shown that monocytes and tissue macrophages isolated from ill patients (e.g., those with rheumatoid arthritis, tuberculosis, and malaria) display higher levels of NOS2, generate higher levels of NO in vitro, and respond better to in vitro activation by cytokines than do cells of normal donors. This suggests that there is an "activating" factor(s) or condition to which human mononuclear phagocytes are exposed in vivo that investigators cannot fully reproduce in in vitro cultures.

There is much correlative data to suggest that human mononuclear phagocyte-generated NO plays important roles in a variety of pathologic states (e.g., resistance to infection and in mediation of inflammation). Also, mononuclear phagocytegenerated NO is probably a physiologic regulator of cell function under basal (normal) conditions. Pharmacological modulation of mononuclear phagocyte NO production will likely be a useful therapeutic option in certain disease states.

\section{References}

1. Moncada S, Higgs A. (1993) The L-arginine-nitric oxide pathway. N. Engl. J. Med. 329: 2002-2012.

2. Bredt DS, Snyder SH. (1994) Nitric oxide: a physiologic messenger molecule. Annu. Rev. Biochem. 63: 175-195.

3. Clancy RM, Abramson SB. (1995) Nitric oxide-a novel mediator of inflammation [Review]. Proc. Soc. Exp. Biol. Med. 210: 93-101.

4. Michel T, Feron O. (1997) Nitric oxide synthases-which, where, how, and why. J. Clin. Invest. 100: 2146-2152.

5. Nathan C, Xie QW. (1994) Regulation of biosynthesis of nitric oxide. J. Biol. Chem. 269: 1372513728.

6. Macmicking J, Xie QW, Nathan C. (1997) Nitric oxide and macrophage function [Review]. Annu. Rev. Immunol. 15: 323-350. 
7. Gross SS, Levi R. (1992) Tetrahydrobiopterin synthesis. An absolute requirement for cytokineinduced nitric oxide generation by vascular smooth muscle. J. Biol. Chem. 267: 25722-25729.

8. Rosenkranz-Weiss P, Sessa WC, Milstien S, et al. (1994) Regulation of nitric oxide synthesis by proinflammatory cytokines in human umbilical vein endothelial cells: elevations in tetrahydrobiopterin levels enhance endothelial nitric oxide synthase specific activity. J. Clin. Invest. 93: 22362243.

9. Nathan C. (1994) Nitric oxide and biopterin: a study in chiaroscuro. J. Clin. Invest. 93: 18751876.

10. Assreuy J, Cunha FQ, Liew FY, Moncada S. (1993) Feedback inhibition of nitric oxide synthase activity by nitric oxide. Br. J. Pharmacol. 108: 833-837.

11. Rogers NE, Ignarro LJ. (1992) Constitutive nitric oxide synthase from cerebellum is reversibly inhibited by nitric oxide formed from L-arginine. Biochem. Biophys. Res. Commun. 189: 242.

12. Albina JE. (1995) On the expression of nitric oxide synthase by human macrophages-why no NO [Review]. J. Leukoc. Biol. 58: 643-649.

13. Denis M. (1994) Human monocytes/macrophages: NO or no NO? J. Leukoc. Biol. 55: 682684.

14. Ochoa JB, Curti B, Peitzman AB, et al. (1992) Increased circulating nitrogen oxides after human tumor immunotherapy: correlation with toxic hemodynamic changes [published erratum appears in J. Natl. Cancer Inst. (1992) 84: 12991]. J. Natl. Cancer Inst. 84: 864-867.

15. Hibbs JB, Jr, Westenfelder C, Taintor R, et al. (1992) Evidence for cytokine-inducible nitric oxide synthesis from L-arginine in patients receiving interleukin-2 therapy [published erratum appears in J. Clin Invest. (1992) 90: 295]. J. Clin. Invest. 89: 867-877.

16. Green LC, de Luzuriaga KR, Wagner DA, et al. (1981) Nitrate biosynthesis in man. Proc. Natl. Acad. Sci. U.S.A. 78: 7764-7768.

17. Ochoa JB, Udekwu AO, Billiar TR, et al. (1991) Polymorphism in promoter region of inducible nitric oxide synthase gene and protection against malaria. Lancet 351: 265-266.

18. Kun JFJ, Mordmuller B, Lell B, et al. (1998) Polymorphism in promoter region of inducible nitric oxide synthase gene and protection against malaria. Lancet 351: 265-266.

19. Feelisch M, Stamler JS. (1996) Methods in Nitric Oxide Research. John Wiley \& Sons, Chichester.

20. Stamler JS, Singel DJ, Loscalzo J. (1992) Biochemistry of nitric oxide and its redox-activated forms. [Review]. Science 258: 1898-1902.

21. Green LC, Wagner DA, Glogowski J, et al. (1982) Analysis of nitrate, nitrite, and $\left[{ }^{15} \mathrm{~N}\right]$ nitrate in biological fluids. Anal. Biochem. 126: 131-138.

22. Granger DL, Taintor RR, Boockvar KS, Hibbs JB,
Jr. (1995) Determination of nitrate and nitrite in biological samples using bacterial nitrate reductase coupled with the Griess reaction. Methods: $A$ Companion to Methods Enzymol. 7: 78-83.

23. Beckman JS, Chen J, Ischiropoulos H, Crow JP. (1994) Oxidative chemistry of peroxynitrite. Methods Enzymol. 233: 229-240.

24. Mannick JB, Asano K, Izumi K, Kieff E, Stamler JS. (1994) Nitric oxide produced by human B lymphocytes inhibits apoptosis and Epstein-Barr virus reactivation. Cell 79: 1137-1 146.

25. Mannick JB, Miao XQ, Stamler JS. (1997) Nitric oxide inhibits Fas-induced apoptosis. J. Biol. Chem. 272: 24125-24128.

26. Reiling N, Kroncke R, Ulmer AJ, et al. (1996) Nitric oxide synthase-expression of the endothelial, $\mathrm{Ca}^{2+} /$ calmodulin-dependent in human $\mathrm{B}$ and $\mathrm{T}$ lymphocytes. Eur. J. Immunol. 26: 511516.

27. Chen LY, Metha JL. (1996) Further evidence of the presence of constitutive and inducible nitric oxide synthase isoforms in human platelets. J. Cardiovasc. Pharmacol. 27: 154-158.

28. Radomski MW, Palmer RM, Moncada S. (1990) Characterization of the L-arginine:nitric oxide pathway in human platelets. Br. J. Pharmacol. 101: 325-328.

29. Malinski T, Radomski MW, Taha Z, Moncada S. (1993) Direct electrochemical measurement of nitric oxide released from human platelets. Biochem. Biophys. Res. Commun. 194: 960-965.

30. Weinberg JB, Misukonis MA, Shami PJ, et al. (1995) Human mononuclear phagocyte inducible nitric oxide synthase (iNOS). Analysis of iNOS mRNA, iNOS protein, biopterin, and nitric oxide production by blood monocytes and peritoneal macrophages. Blood 86: 1184-1195.

31. Salvemini D, de Nucci G, Gryglewski RJ, Vane JR. (1989) Human neutrophils and mononuclear cells inhibit platelet aggregation by releasing a nitric oxide-like factor. Proc. Natl. Acad. Sci. U.S.A. 86: 6328-6332.

32. Hunt NC, Goldin RD, (1992) Nitric oxide production by monocytes in alcoholic liver disease. J. Hepatol. 14: 146-150.

33. Middleton SJ, Cuthbert AW, Shorthouse M, Hunter JO. (1993) Nitric oxide affects mammalian distal colonic smooth muscle by tonic neural inhibition. Br. J. Pharmacol. 108: 974-979.

34. Martin JH, Edwards SW. (1993) Changes in mechanisms of monocyte/macrophage-mediated cytotoxicity during culture. Reactive oxygen intermediates are involved in monocyte-mediated cytotoxicity, whereas reactive nitrogen intermediates are employed by macrophages in tumor cell killing. J. Immunol. 150: 3478-3486.

35. Wickramasinghe SN, Hasan R. (1993) Possible role of macrophages in the pathogenesis of ethanol-induced bone marrow damage. $\mathrm{Br}$. J. Haematol. 83: 574-579. 
36. Petit JF, Phan-Bich L, Lemaire G, Martinache C, Lopez M. (1993) During their differentiation into macrophages, human monocytes acquire cytostatic activity independent of NO and TNF alpha. Res. Immunol. 144: 277-280; discussion 2994298.

37. Chu SC, Wu HP, Banks TC, Eissa NT, Moss J. (1995) Structural diversity in the $5^{\prime}$-untranslated region of cytokine-stimulated human inducible nitric oxide synthase mRNA. J. Biol. Chem. 270: 10625-10630.

38. Eissa NT, Strauss AJ, Haggerty CM, et al. (1996) Alternative splicing of human inducible nitricoxide synthase mRNA. Tissue-specific regulation and induction by cytokines. J. Biol. Chem. 271: 27184-27187.

39. Granger DL, Hibbs JB, Jr, Perfect JR, Durack DT. (1988) Specific amino acid (L-arginine) requirement for the microbiostatic activity of murine macrophages. J. Clin. Invest. 81: 1129-1136.

40. Cameron ML, Granger DL, Weinberg JB, Kozumbo WJ, Koren HS. (1990) Human alveolar and peritoneal macrophages mediate fungistasis independently of L-arginine oxidation to nitrite or nitrate. Am. Rev. Respir. Dis. 142: 1313-1319.

41. Denis M. (1991) Tumor necrosis factor and granulocyte macrophage-colony stimulating factor stimulate human macrophages to restrict growth of virulent Mycobacterium avium and to kill avirulent $M$. avium: killing effector mechanism depends on the generation of reactive nitrogen intermediates. J. Leukoc. Biol. 49: 380-387.

42. Sherman MP, Loro ML, Wong VZ, Tashkin DP. (1991) Cytokine-and Pneumocystis carinii-induced L-arginine oxidation by murine and human pulmonary alveolar macrophages. $J$. Protozool. 38: 234S-236S.

43. Muñoz-Fernández MA, Fernández MA, Fresno M. (1992) Activation of human macrophages for the killing of intracellular Trypanosoma cruzi by TNF-alpha and IFN-gamma through a nitric oxide-dependent mechanism. Immunol. Lett. 33: 35: 40.

44. Harwix S, Andreesen R, Ferber E, Schwamberger G. (1992) Human macrophages secrete a tumoricidal activity distinct from tumour necrosis factor- $\alpha$ and reactive nitrogen intermediates. Res. Immunol. 143: 89-94.

45. Murray HW, Teitelbaum RF. (1992) L-argininereactive nitrogen intermediates and the antimicrobial effect of activated human mononuclear phagocytes. J. Infect. Dis. 165: 513-517.

46. Padgett EL, Pruett SB. (1992) Evaluation of nitrite production by human monocyte-derived macrophages. Biochem. Biophys. Res. Commun. 286: 775-781.

47. Ben-Efraim S, Tak C, Fieren MJWA, et al. (1993) Activity of human peritoneal macrophages against a human tumor: role of tumor necrosis factor- $\alpha$, PGE2 and nitrite, in vitro studies. Immunol. Lett. 37: 27-33.

48. Bermudez LE. (1993) Differential mechanisms of intracellular killing of Mycobacterium avium and Listeria monocytogenes by activated human and murine macrophages. The role of nitric oxide. Clin. Exp. Immunol. 91: 277-281.

49. Keller R, Keist R, Joller P, Groscurth P. (1993) Mononuclear phagocytes from human bone marrow progenitor cells; morphology, surface phenotype, and functional properties and activated cells. Clin. Exp. Immunol. 91: 176-182.

50. Sakai N, Milstien S. (1993) Availability of tetrahydrobiopterin is not a factor in the inability to detect nitric oxide production by human macrophages. Biochem. Biophys. Res. Commun. 193: 378-383.

51. Schneemann $M$, Schoedon G, Hofer S, et al. (1993) Nitric oxide synthase is not a constituent of the antimicrobial armature of human mononuclear phagocytes. J. Infect. Dis. 167: 1358-1363.

52. Barnewall RE, Rikihisa Y. (1994) Abrogation of gamma interferon-induced inhibition of Ehrlichia chaffeensis infection in human monocytes with iron-transferrin. Infect. Immun. 62: 4804-4810.

53. Essery SD, Saadi AT, Twite SJ, et al. (1994) Lewis antigen expression on human monocytes and binding of pyrogenic toxins. Agents Actions 41: 108-110.

54. Gyan B, Troye-Blomberg M, Perlmann P, Bjorkman A. (1994) Human monocytes cultured with and without interferon-gamma inhibit Plasmodium falciparum parasite growth in vitro via secretion of reactive nitrogen intermediates. Parasite Immunol. 16: 371-375.

55. Leibovich SJ, Polverini PJ, Fong TW, Harlow LA, Koch ARE. (1994) Production of angiogenic activity by human monocytes requires an L-arginine/nitric oxide-synthase-dependent effector mechanism. Proc. Natl. Acad. Sci. U.S.A. 91: 41904194.

56. Martin JH, Edwards SW. (1994) Interferongamma enhances monocyte cytotoxicity via enhanced reactive oxygen intermediate production. Absence of an effect on macrophage cytotoxicity is due to failure to enhance reactive nitrogen intermediate production. Immunology 81: 592-597.

57. Zembala M, Siedlar M, Marcinkiewicz J, Pryjma J. (1994) Human monocytes are stimulated for nitric oxide release in vitro by some tumor cells but not by cytokines and lipopolysaccharide. Eur. J. Immunol. 24: 435-439.

58. Siedlar M, Marcinkiewicz M, Zembala M. (1995) MHC class I and class II determinants and some adhesion molecules are engaged in the regulation of nitric oxide production in vitro by human monocytes stimulated with colon carcinoma cells. Clin. Immunol. Immunopathol. 77: 380-384. 
59. Bose M, Farnia P. (1995) Proinflammatory cytokines can significantly induce human mononuclear phagocytes to produce nitric oxide by a cell maturation-dependent process. Immunol. Lett. 48: 59-64.

60. Reiling N, Ulmer AJ, Duchrow M, et al. (1994) Nitric oxide synthase: mRNA expression of different isoforms in human monocytes/macrophages. Eur. J. Immunol. 24: 1941-1944.

61. Bukrinsky MI, Nottet $\mathrm{H}$, Schmidt-Mayerova $\mathrm{H}$, et al. (1995) Regulation of nitric oxide synthase activity in human immunodeficiency virus type 1 (HIV-1)-infected monocytes-implications for HIV-associated neurological disease. J. Exp. Med. 181: 735-745.

62. Bagasra O, Bobroski L, Sarker A, et al. (1997) Absence of the inducible form of nitric oxide synthase in the brains of patients with the acquired immunodeficiency syndrome. J. Neurovirol. 3: 153-167.

63. Liu J, Zhao ML, Brosnan CF, Lee SC. (1996) Expression of type II nitric oxide synthase in primary human astrocytes and microglia: role of Il-1beta and IL-1 receptor antagonist. J. Immunol. 157: 3569-3576.

64. Zinetti M, Fantuzzi G, Delgado R, et al. (1995) Endogenous nitric oxide production by human monocyte cells regulates LPS-induced TNF production. Eur. Cytokine Network 6: 45-48.

65. Condino-Neto A, Muscara MN, Bellinatipires R, et al. (1996) Effect of therapy with recombinant human interferon-gamma on the release of nitric oxide by neutrophils and mononuclear cells from patients with chronic granulomatous disease. J. Interferon. Cytokine Res. 16: 357-364.

66. Kashem A, Endoh M, Yano N, et al. (1996) Expression of inducible-NOS in human glomerulonephritis-the possible source is infiltrating monocytes/macrophages. Kidney Int. 50: 392-399.

67. St. Clair EW, Wilkinson WE, Lang T, et al. (1996) Increased expression of blood mononuclear cell nitric oxide synthase type 2 in the rheumatoid arthritis patients. J. Exp. Med. 184: 1173-1178.

68. Wang CL, Su MH, Chao TY, Shaio Mf, Yang KD. (1996) When do human macrophages release nitric oxide? Variable effects of certain in vitro cultural and in vivo resident conditions. Proc. Natl. Sci. Counc. Repub. China B 20: 65-70.

69. Amin AR, Attur M, Vyas P, et al. (1997) Expression of nitric oxide synthase in human peripheral blood mononuclear cells and neutrophils. J. Inflam. 47: 190-205.

70. Polack B, Pernod G, Barro C, Doussiere J. (1997) Role of oxygen radicals in tissue factor induction by endotoxin in blood monocytes. Haemostasis 27: 193-200.

71. Saha DC, Astiz ME, Lin RY, Rackow EC, Eales LJ. (1997) Monophosphoryl lipid A stimulated upregulation of nitric oxide synthase and nitric ox- ide release by human monocytes in vitro. Immunopharmacology 37: 175-184.

72. Snell JC, Chernyshev O, Gilbert DL, Colton CA. (1997) Polyribonucleotides induce nitric oxide production by human monocyte-derived macrophages. J. Leukoc. Biol. 62: 369-373.

73. Ding AH, Nathan CF, Stuehr DJ. (1988) Release of reactive nitrogen intermediates and reactive oxygen intermediates from mouse peritoneal macrophages. comparison of activating cytokines and evidence for independent production. J. Immunol. 141: 2407-24112.

74. Zhou AQ, Chen ZF, Rummage JA, et al. (1995) Exogenous interferon-gamma induces endogenous synthesis of interferon-alpha and -beta by murine macrophages for induction of nitric oxide synthase. J. Interferon Cytokine Res. 15: 897-904.

75. Diefenbach A, Schindler H, Donhauser N, et al. (1998) Type 1 interferon (IFN-alpha/beta) and type 2 nitric oxide synthase regulate the innate immune response to a protozoan parasite. Immunity 8: 77-87.

76. Sharara AI, Perkins DJ, Misukonis MA, et al. (1997) Interferon (IFN)-alpha activation of human blood mononuclear cells in vitro and in vivo for nitric oxide synthase (NOS) type 2 mRNA and protein expression-possible relationship of induced NOS2 to the anti-hepatitis C effects of IFN-alpha in vivo. J. Exp. Med. 186: 1495-1502.

77. Vial T, Descotes J. (1995) Immune-mediated side-effects of cytokines in humans. Toxicology 105: 32-57.

78. Levesque MC, Ward FE, Jeffery DR, Weinberg JB. (1998) Interferon beta-la induced polyarthritis in a patient with the HLA-DRB I*0404 allele. Arth. Rheum. In press.

79. Kolb JP, Paul-Eugene N, Damais C, et al. (1994) Interleukin-4 stimulates cGMP production by IFN- $\gamma$-activated human monocytes. Involvement of the nitric oxide synthase pathway. J. Biol. Chem. 269: 9811-9816.

80. Mautino G, Paul-Eugene N, Chanez P, et al. (1994) Heterogeneous spontaneous and interleukin-4-induced nitric oxide production by human monocytes. J. Leukoc. Biol. 56: 15-20.

81. Paul-Eugene N, Kolb JP, Damais C, Yamaoka K, Dugas B. (1994) Regulatory role of nitric oxide in the IL-4-induced IgE production by normal human peripheral blood mononuclear cells. Lymphokine Cytokine Res. 13: 287-293.

82. Lecoanet-Henchoz S, Gauchat JF, Aubry JP, et al. (1995) CD23 regulates monocyte activation through a novel interaction with the adhesion molecules CDllb-Cd18 and CD11c-CD18. Immunity 3: 199-125.

83. Paul-Eugene N, Kolb JP, Sarfati M, et al. (1995) Ligation of CD23 activated soluble guanylate cyclase in human monocytes via an L-argininedependent mechanism. J. Leukoc. Biol. 57: 160167. 
84. Paul-Eugene N, Pene J, Bousquet J, Dugas B. (1995) Role of cyclic nucleotides and nitric oxide in blood mononuclear cell IgE production stimulated by IL-4. Cytokine 7: 64-69.

85. Paul-Eugene N, Mossalayi D, Sarfati M, et al. (1995) Evidence for a role of Fc epsilon RII/CD23 in the IL-4-induced nitric oxide production by normal human mononuclear phagocytes. Cell. Immunol. 163: 314-318.

86. Dugas N, Vouldoukis L, Becherel P, et al. (1996) Triggering of $\mathrm{CD} 23 \mathrm{~b}$ antigen by anti-CD23 monoclonal antibodies induces interleukin-10 production by human macrophages. Eur. J. Immunol. 26: 1394-1398.

87. Vouldoukis I, Riverosmoreno V, Dugas V, et al. (1995) The killing of leishmania major by human macrophages is mediated by nitric oxide induced after ligation of the Fc-epsilon-RII/Cd23 surface antigen. Proc. Natl. Acad. Sci. U.S.A. 92: 78047808.

88. Aubry JP, Dugas N, Lecoanet-Henchoz S, et al. (1997) The 25-Kda soluble CD23 activates type III constitutive nitric oxide-synthase activity via CDIlb and CDIlc expressed by human monocytes. J. Immunol. 159: 614-622.

89. Vouldoukis I, Becherel PA, Riverosmoreno V, et al. (1997) Interleukin-10 and interleukin-4 inhibit intracellular killing of leishmania infantum and leishmania major by human macrophages by decreasing nitric oxide generation. Eur. J. Immunol. 27: 860-865.

90. Schneemann M, Schoedon G, Linscheid P, et al. (1997) Nitrite generation in interleukin-4treated human macrophage cultures does not involved the nitric oxide synthase pathway. $J$. infect. Dis. 175: 130-135.

91. Dumarey $\mathrm{CH}$, Labrousse V, Rastogi N, Vargaftig BB, Bachelet M. (1994) Selective Mycobacterium avium-induced production of nitric oxide by human monocyte-derived macrophages. J. Leukoc. Biol. 56: 36-40.

92. Naotunne TS, Karunaweera ND, Mendis KN, Carter R. (1994) Cytokine-mediated inactivation of malarial gametocytes is dependent on the presence of white blood cells and involves reactive nitrogen intermediates. Immunology 78: 555562.

93. Seitzer U, Scheeltoellner D, Toellner KM, et al. (1997) Properties of multinucleated giant cells in a new in vitro model for human granuloma formation. J. Pathol. 182: 99-105.

94. Pietraforte D, Tritarelli E, Testa U, Minetti M. (1994) gp120 HIV envelope glycoprotein increases the production of nitric oxide in human monocyte-derived macrophages. J. Leukoc. Biol. 55: $175-182$.

95. Tufano MA, Rossano F, Catalanotti P, et al. (1994) Properties of Yersinia enterocolitica porins: interference with biological functions of phagocytes, nitric oxide production and selective cytokine release. Res. Microbiol. 145: 297-307.

96. Belenky SN, Robbins RA, Rubinstein I. (1993) Nitric oxide synthase inhibitors attenuate human monocyte chemotaxis in vitro. J. Leukoc. Biol. 53: 498-503.

97. De Maria R, Cifone MG, Trotta R, et al. (1994) Triggering of human monocyte activation through CD69, a member of the natural killer cell gene complex family of signal transducing receptors. J. Exp. Med. 180: 1999-2004.

98. Perez-Mediavilla LA, Lopez-Zabalza MJ, Calonge $M$, et al. (1995) Inducible nitric oxide synthase in human lymphomononuclear cells activated by synthetic peptides derived from extracellular matrix proteins. FEBS Lett. 357: 121-124.

99. McLachlan JA, Serkin CD, Bakouche O. (1996) Dehydroepiandrosterone modulation of lipopolysaccharide-stimulated monocyte cytotoxicity. J. Immunol. 156: 328-335.

100. Magazine HI, Liu Y, Bilfinger TV, Fricchione GL, Stefano GB. (1996) Morphine-induced conformational changes in human monocytes, granulocytes, and endothelial cells and in invertebrate immunocytes and microglia are mediated by nitric oxide. J. Immunol. 156: 4845-4850.

101. Aymerich MS, Bengoecheaalonso MT, Lopezzabalza MJ, Santiago E, Lopezmoratalla N. (1998) Inducible nitric oxide synthase (iNOS) expression in human monocytes triggered by beta-endorphin through an increase in cAMP. Biochem. Biophys. Res. Commun. 245: 717-721.

102. Stefano GB, Liu Y, Goligorsky MS. (1996) Cannabinoid receptors are coupled to nitric oxide release in invertebrate immunocytes microglia, and human monocytes. J. Biol. Chem. 271: 19238-19242.

103. King JM, Srivastava KD, Stefano GB, et al. (1997) Human monocyte adhesion is modulated by endothelin B receptor-coupled nitric oxide release. J. Immunol. 158: 880-886.

104. Lammas DA, Stober C, Harvey CJ, et al. (1997) ATP-induced killing of mycobacteria by human macrophages is mediated by purinergic P2ZP2X(7)) receptors. Immunity 7: 433-444.

105. Vitek MP, Snell J, Dawson H, Colton CA. (1997) Modulation of nitric oxide production in human macrophages by apolipoprotein-E and amyloidbeta peptide. Biochem. Biophys. Res. Commun. 240: 391-394.

106. Criado-Jimenez M, Rivas-Cabanero L, MartinOterino JA, Lopez-Novoa JM, Sanchez-Rodriguez A. (1995) Nitric oxide production by mononuclear leukocytes in alcoholic cirrhosis. J. Mol. med. 73: 31-33.

107. Laffi G, Foschi M, Masini E, et al. (1995) Increased production of nitric oxide by neutrophils and monocytes from cirrhotic patients with ascites and hyperdynamic circulation. Hepatology 22: $1666-1673$. 
108. Masini E, Mugnai L, Foschi M, et al. (1995) Changes in the production of nitric oxide and superoxide by inflammatory cells in liver cirrhosis. Int. Arch. Allergy Immunol. 107: 197-198.

109. Majano PL, García-Monzón C, López-Cabrera M, et al. (1998) Inducible nitric oxide synthase expression in chronic viral hepatitis. Evidence for a virus-induced gene upregulation. J. Clin. Invest. 101: 1343-1352.

110. Majano PL, Garciamonzon C, Lopezcabrera M, et al. (1998) Inducible nitric oxide synthase expression in chronic viral hepatitis. J. Clin. Invest. 101: 1343-1352.

111. Kobzik L, Bredt DS, Lowenstein CJ, et al. (1993) Nitric oxide synthase in human and rat lung: immunocytochemical and histochemical localization. Am. J. Respir. Cell. Mol. Biol. 9: 371-377.

112. Tracey WR, Xue C, Klinghofer V, et al. (1994) immunochemical detection of inducible NO synthase in human lung. Am. J. Physiol. 266: L722L727.

113. Haddad IY, Pataki G, Hu P, et al. (1994) Quantitation of nitrotyrosine levels in lung sections of patients and animals with acute lung injury. J. Clin. Invest. 94: 2407-2413.

114. Kooy NW, Royall JA, Ye YZ, Kelly DR, Beckman JS. (1995) Evidence for in vivo peroxynitrite production in human acute lung injury. Am. J. Respir. Crit. Care Med. 151: 1250-1254.

115. McDermott CD, Gavita SM, Shennib H, Giaid A. (1997) Immunohistochemical localization of nitric oxide synthase and the oxidant peroxynitrite in lung transplant recipients with obliterative bronchiolitis. Transplantation 64: 270-274.

116. Nozaki Y, Hasegawa Y, Ichiyama S, Nakashima I, Shimokata K. (1997) Mechanism of nitric oxidedependent killing of mycobacterium bovis BCG in human alveolar macrophages. Infect. Immun. 65: 3544-3647.

117. Kumar V, Jindal SK, Ganguly NK. (1995) Release of reactive oxygen and nitrogen intermediates from monocytes of patients with pulmonary tuberculosis. Scand. J. Clin. Lab. Invest. 55: 163169.

118. Nicholson S, Bonecinialmeida MDG, Silva LE, Jr, et al. (1996) Inducible nitric oxide synthase in pulmonary alveolar macrophages from patients with tuberculosis. J. Exp. Med. 183: 2293-2302.

119. Tunctan B, Okur H, Calisir $\mathrm{CH}$, et al. (1998) Comparison of nitric oxide production by monocyte/macrophages in healthy subjects and patients with active pulmonary tuberculosis. Pharmacol. Res. 37: 219-226.

120. Wang $\mathrm{CH}$, Liu CY, Lin HC, et al. (1998) Increased exhaled nitric oxide in active pulmonary tuberculosis due to inducible NO synthase upregulation in Alveolar macrophages. Eur. Respir. J. 11: 809-815.

121. Beckman JS, Ye YZ, Anderson PG, et al. (1994) Extensive nitration of protein tyrosines in hu- man atherosclerosis detected by immunohistochemistry. Biol. Chem. Hoppe-Seyler 375: 81-88.

122. Buttery LDK, Springall DR, Chester AH, et al. (1996) Inducible nitric oxide synthase is present within human atherosclerotic lesions and promotes the formation and activity of peroxynitrite. Lab. Invest. 75: 77-85.

123. Wilcox JN, Subramanian RR, Sundell CL, et al. (1997) Expression of multiple isoforms of nitric oxide synthase in normal and atherosclerotic vessels. Arterioscler. Thromb. Vasc. Biol. 17: 24792488.

124. Luoma JS, Stralin P, Marklund SL, et al. (1998) Expression of extracellular SOD and iNOS in macrophages and smooth muscle cells in human and rabbit atherosclerotic lesions-colocalization with epitopes characteristics oxidized LDL and peroxynitrite-modified proteins. Arterioscler. Thromb. Vasc. Biol. 18: 157-167.

125. Lafond-Walker A, Chen CL, Augustine S, et al. (1997) Inducible nitric oxide synthase expression in coronary arteries of transplanted human hearts with accelerated graft arteriosclerosis. Am. J. Pathol. 151: 919-925.

126. Wildhirt SM, Dudek RR, Suzuki H, Bing RJ. (1995) Involvement of inducible nitric oxide synthase in the inflammatory process of myocardial infarction. Int. J. Cardiol. 50: 253-261.

127. Weyand CM, Wagner AD, Bjornsson J, Goronzy JJ. (1996) Correlation of the topographical arrangement and the functional pattern of tissueinfiltrating macrophages in giant cell arteritis. J. Clin. Invest. 98: 1642-1649.

128. Sakurai H, Kohsaka H, Liu MF, et al. (1995) Nitric oxide production and inducible nitric oxide synthase expression in inflammatory arthritides. J. Clin. Invest. 96: 2357-2363.

129. McInnes LB, Leung BP, Field M, et al. (1996) Production of nitric oxide in the synovial membrane of rheumatoid and osteoarthritis patients. J. Exp. Med. 184: 1519-1524.

130. Grabowski PS, Wright PK, Vanthof RJ, et al. (1997) Immunolocalization of inducible nitric oxide synthase in synovium and cartilage in rheumatoid arthritis and osteoarthritis. $B r . J$. Rheumatol. 36: 651-655.

131. Perkins DJ, St. Clair WE, Misukonis MA, Weinberg JB. (1998) Reduction of NOS2 overexpression in rheumatoid arthritis patients treated with anti-TNF-alpha monoclonal antibody (cA2). Arthritis. Rheum. In press.

132. Moilanen E, Moilanen T, Knowles $R$, et al. (1997) Nitric oxide synthase is expressed in human macrophages during foreign body inflammatory. Am. J. Pathol. 150: 881-887.

133. Watkins SC, Macaulay W, Turner D, et al. (1997) Identification of inducible nitric oxide synthase in human macrophages surrounding loosened hip prostheses. Am. J. Pathol. 150: 1199-1206.

134. Thomsen LL, Miles DW, Happerfield L, et al. 
(1995) Nitric oxide synthase activity in human breast cancer. $\mathrm{Br}$. J. Cancer 72: 41-44.

135. Ambs S, Merriam WG, Bennett WP, et al. (1998) Frequent nitric oxide synthase-2 expression in human colon adenomas-implication for tumor angiogenesis and colon cancer progression. Cancer Res. 58: 334-341.

136. Thomsen LL, Lawton FG, Knowles RG, et al. (1994) Nitric oxide synthase activity in human gynecological cancer. Cancer Res. 54: 1352-1354.

137. Cobbs CS, Brenman JE, Aldape KD, Bredt DS, Israel MA. (1995) Expression of nitric oxide synthase in human central nervous system tumors. Cancer Res. 55: 727-730.

138. Anstey NM, Weinberg JB, Hassanali $M$, et al. (1996) Nitric oxide in Tanzanian children with malaria. Inverse relationship between malaria severity and nitric oxide production/nitric oxide synthase type 2 expression. J. Exp. Med. 184: 557-567.

139. Furusu A, Miyazaki M, Abe K, et al. (1998) Expression of endothelial and inducible nitric oxide synthase in human glomerulonephritis. Kidney Int. 53: 1760-1768.

140. Singer II, Kawka DW, Scott S, et al. (1996) Expression of inducible nitric oxide synthase and nitrotyrosine in colonic epithelium in inflammatory bowel disease. Gastroenterology 111: 871885.

141. Ikeda I, Kasajima T, Ishiyama S, et al. (997) Distribution of inducible nitric oxide synthase in ulcerative colitis. Am. J. Gastroenterol. 92: 13391341.

142. Mannick EE, Bravo LE, Zarama G, et al. (1996) Inducible nitric oxide synthase, nitrotyrosine, and apoptosis in Helicobacter pylori gastritis: effect of antibiotics and antioxidants. Cancer Res. 56: 3238-3243.

143. ter Steege J, Burrman W, Arends JW, Forget P. (1997) Presence of inducible nitric oxide synthase, nitrotyrosine, $\mathrm{CD} 68$, and $\mathrm{CD} 14$ in the small intestine in celiac disease. Lab. Invest. 77: 29-36.

144. Bo L, Dawson TM, Wesselingh S, et al. (1994) Induction of nitric oxide synthase in demyelinating regions of multiple sclerosis brains. Ann. Neurol. 36: 778-786.

145. Bagasra O, Michaels FH, Zheng YM, et al. (1995)
Activation of the inducible form of nitric oxide synthase in the brains of patients with multiple sclerosis. Proc. Natl. Acad. Sci. U.S.A. 92: 1204112045.

146. DeGroot CJA, Ruuls SR, Theeuwes JWM, Dijkstra CD, Vandervalk P. (1997) Immunocytochemical characterization of the expression of inducible and constitutive isoforms of nitric oxide synthase in demyelinating multiple sclerosis lesions. J. Neuropathol. Exp. Neurol. 56: 10-20.

147. Hooper DC, Bagasra O, Marini JC, et al. (1997) Prevention of experimental allergic encephalomyelitis by targeting nitric oxide and peroxynitrite: implications for the treatment of multiple sclerosis. Proc. Natl. Acad. Sci. U.S.A. 94: 25282533.

148. Myatt L, Eis ALW, Brockman DE, et al. (1997) Inducible (type II) nitric oxide synthase in human placental villous tissue of normotensive, pre-eclamptic and intrauterine growth-restricted pregnancies. Placenta 18: 261-268.

149. Zarlingo TJ, Eis ALW, Brockman DE, Kossenjans W, Myatt L. (1997) Comparative localization of endothelial and inducible nitric oxide synthase isoforms in haemochorial and epitheliochorial placentae. Placenta 18: 511-520.

150. Eis ALW, Brockman DE, Myatt L. (1997) Immunolocalization of the inducible nitric oxide synthase isoform in human fetal membranes. Am. J. Reprod. Immunol. 38: 289-294.

151. Condino-Neto A, Muscara MN, Grumach AS, Carneiro-Sampaio MM, De Nucci G. (1993) Neutrophils and mononuclear cells from patients with chronic granulomatous disease release nitric oxide. Br. J. Clin. Pharmacol. 35: 485-490.

152. López-Moratalla N, Calleja A, Gonzalez A, et al. (1996) Inducible nitric oxide synthase in monocytes from patients with Graves' disease. Biochem. Biophys. Res. Commun. 226: 723-729.

153. Kim C, Schinkel C, Fuchs D, et al. (1995) Interleukin-13 effectively down-regulates the monocyte inflammatory potential during traumatic stress. Arch. Surg. 130: 1330-1336.

154. Dias-Da-Motta P, Arruda VR, Muscara MN, et al. (1996) The release of nitric oxide and superoxide anion by neutrophils and mononuclear cells from patients with sickle cell anaemia. $\mathrm{Br}$. J. Haematol. 93: 333-340. 